\title{
Beginning of Human Life: Doubts and Controversies
}

\author{
${ }^{1}$ Lara Spalldi Barišić, ${ }^{2}$ Asim Kurjak, ${ }^{3}$ Milan Stanojević
}

\begin{abstract}
The beginning of human life and the whole mystery about it has fascinated people from time immemorial. It has been the subject of various scientific researches and religious debates. Different views on "the beginning" and distinct definitions are peculiar from individual to individual, in diverse countries, cultures, and religions. Substantial progress has been made so far that philosophers, scientists, ethicists, sociologists, and theologies are closer and closer to achieve some consensus, realizing that most of their views can be seen as complementary and do not exclude each other. Evaluating the process of development of human life, we can surely say that at some point there is the beginning and the end. Pointing out exact moments in time remains unascertained. Scientifically, from the biological standpoint, there are several moments which are more or less equally important and are rather seen as a continuous dynamic process that develops fluently.
\end{abstract}

Keywords: Beginning of human life, Bioethics, Embryo, Fertilization, Religion, Science.

How to cite this article: Spalldi Barišić L, KurjakA, Stanojević M. Beginning of Human Life: Doubts and Controversies. J Ultrasound Obstet Gynecol 2018;12(4):262-281.

\section{Source of support: Nil}

\section{Conflict of interest: None}

\section{INTRODUCTION}

This golden era of medicine, science, and technology stimulates our endless drive to push medical evolution even more forward. State of the art medicine requires cutting-edge technology used by individuals who continually invest in their knowledge, improve and embrace innovations to improve the quality of patient life.

As mentioned earlier, technology opens a range of possibilities which are all produced by science but often are still missing adequate evaluation as well as an understanding of different alternatives and possible consequences.

\footnotetext{
${ }^{1}$ Lecturer, ${ }^{2,3}$ Professor

${ }^{1}$ Department of Obstetrics and Gynecology, Private Clinic Veritas, Zagreb, Croatia

2Department of Obstetrics and Gynecology, Medical School University of Zagreb, Zagreb, Croatia

${ }^{3}$ Department of Obstetrics and Gynecology, Medical School University of Zagreb, Clinical Hospital Sveti Duh, Zagreb, Croatia

Corresponding Author: Asim Kurjak, Professor, Department of Obstetrics and Gynecology, Medical School University of Zagreb, Zagreb, Croatia, email asim.kurjak@public.carnet.hr
}

Our life is far richer than it can be illustrated only by science and cannot be always proven through logical deduction. Other insights are necessary to get the whole picture. The views of the great religions certainly must be taken into consideration.

Nowadays, we are witnessing a general rise of interest in the interrelation between science and religion. It is subject of persistent debate and polemic in philosophy and theology.

The dispute is still not ended on the question to what extent religion and science are compatible. Over the years, science and religion had to adopt the new findings and required some integration and reinterpretation on their views on certain important subjects. These blending of theory and principle in science and religion will endure in the future.

\section{What is Science? And... What is Religion?}

Following the old Chinese saying "the path to wisdom begins by calling things by their right names", some common terminology and several definitions should be given to better understand the interaction between science and religion. For a better understanding of the interaction and the scope of science and religion are not constant, and the interpretation of each has changed through time and across the different cultures. ${ }^{1}$

The etymological Latin roots of science and religion, in the ancient era both science (Lat. scientia) and religion (Lat. religio) from the etymological point of view, were assumed as inner abilities of an individual or assets, rather than actual sources of knowledge. ${ }^{2}$

The term "religion" meaning the belief in and worship (controlling power, especially a personal god or gods). This term was barely used before the 17 th century. ${ }^{1}$

The considerably broader meaning and systematically used term for world religions were used by some anthropologist like Taylor.

The term "science" has become more common from 19th and emerged from "natural philosophy" which studied the nature and universe and was antecedent to the evolution of modern science. ${ }^{2-5}$

Science differs from the religion in the way that its truth must be experimentally verified and its methodo logical knowledge can be learned. ${ }^{6}$ With other words, there is a hypothesis that has to be tested by experiments, and with the gained knowledge one must form the theories that best apply the observed evidence (evidence-based). 
The theories and all scientific knowledge can be adjusted, added or even rejected by new insight or evidence. ${ }^{7}$

Religion is dominated by irrational moment and science by a rational moment. Intellectual knowledge in science is expressed in the model of mathematical formulas and equations (quantitatively), but religion, on the other hand, uses the form of metaphors and abstractions (qualitatively). 6,8,9

The other way of explaining it is that science concerns of the natural world and does not use supernatural entities such as gods, angels or karma; whereas religion concerns both natural and supernatural.

Natural philosophers like Isaac Newton, Robert Hook, Johannes Kepler, and Robert Boyle, preferred the naturalistic explanations but sometimes also referred to supernatural means in their natural philosophy (contemporary assigned as science). Later on, others like Huxley et al. tried to indorsee science without religious canons. ${ }^{5}$

Albert Einstein ${ }^{10}$ states in his book on religion and science: "For science can only ascertain what is, but not what should be, and outside of its domain value judgments of all kinds remain necessary. Religion, on the other hand, deals only with evaluations of human thought and action; it cannot justifiably speak of facts and relationships between facts..."10

"Now, even though the realms of religion and science in themselves are clearly marked off from each other, nevertheless there exist between the two strong reciprocal relationships and dependencies. Though religion may be that which determine the goals, it has, nevertheless, learned from science, in the broadest sense, what means will contribute to the attainment of the goals it has set up."10

It was in the 1960s when the systematic study of science and religion started. Until than predominant view was that science and religion were either in the fight against each other or indifferent to each other. ${ }^{11}$ Barbour $^{12}$ and Torrance ${ }^{13}$ try to argue on this by comparing the methodology and theory in both fields. Since that time, science and religion are recognized fields of study. Zygon was the title of the first journal specializing in science and religion issued in 1966.

Speaking in general about "science" and "religion" and discussing their interference and relationship, in general, may be pointless since the "science and religion" try to ignore the definitions! ${ }^{14}$ As Clark in 2014, ${ }^{15}$ suggested, the relation between generally acknowledged statements of the science can be contrasted with specific statements of a certain religion. ${ }^{5}$ In the modern public circles, the most dominant debate between science and religion involve the evolutionary theory and creationismintelligent design. ${ }^{5}$

In the last several decades, the conciliatory public statement has been issued by the Church leaders on the statement on evolutionary theory. Pope John Paul II affirmed the evolutionary theory in his message to the Pontifical Academy of Sciences. However, he rejected it from the "human soul", which he saw as the result of a separate, special creation. ${ }^{5}$

As noted, up until recently, most studies and investigation on the relationship between science and religion have focused mainly on Christian religion and tradition. Nowadays, we investigate all other non-Christian traditions and religions such as Judaism, Hinduism, Buddhism, and Islam contributing to the richer picture of interactions.

\section{Science and Religion: Models of the Interaction}

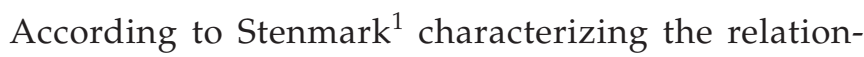
ship between science and religion we can identify three different opinions:

- Independence opinion: Religion and science do not have any overlapping

- Contact opinion: Between religion and science some overlapping can be found, further defined with the concept of conflict and harmony.

- The union of domains of science and religion According to Barbour, ${ }^{13}$ most widely accepted, the best models of the interaction of science and religion are:

- Independence model: Science and religions search diverse areas and ask different queries. Gould with his NOMA principle (non-overlapping magisteria) declared that non-existence of conflict between science and religion appears due to the lack of overlap between their particular areas of professional capability. ${ }^{16}$

- Conflict model: Declares the existence of an eternal conflict between science and religion. This conflict is based on two historical stories: The Trail of Galileo ${ }^{17}$ and the Reception of Darwinism, ${ }^{18}$ saying that the conflict is immense due to the same area of interest of both disciplines.

This model is in contemporary spheres present in minority. The majority of authors believe this model relies on a superficial and prejudiced interpretation of the historical record. ${ }^{5}$

- Dialogue model: science and religion have a mutual relationship. Even though these two fields stay separate, they communicate! The science and religion are epidemiologically overlapping and they indeed have common theories, methods, and concepts. ${ }^{19}$

- Integration model relying on the wide association between science and theology.

\section{Scientific Study of Science and Religion}

Throughout history, science and religion are even more investigated in the "scientific study of the religion" which 
can be traced from the 17th century on. In the 19th and early 20th century new scientific disciplines like anthropology, sociology and psychology appeared, exploring and clarifying different religious beliefs. ${ }^{5}$

The divergence of the assumptions is colorful. For example, the sociologist Durkheim ${ }^{20}$ thought about "religious beliefs as social glue". Freud ${ }^{21}$ psychologist known on his bizarre explanations, considered "religious belief as an illusion", as a longing of a child for a paternal figure. These two authors along with Karl Marx and Max Weber suggested the version of secularization thesis making the religion less important if faced with modern technology, science, and culture. Later on, several authors stated that the religious beliefs were more diverse than it was supposed previously. ${ }^{5}$

The cognitive science of religion is the contemporary advancements in the scientific studying of religion. This includes multidisciplinary fields, such as developmental psychology, anthropology, philosophy, and cognitive psychology among others. ${ }^{5}$

\section{Academia and Religious Beliefs}

Up to the 19th and early 20th century, it was very prevalent for the scientist to possess religious beliefs which had guided their work. Natural philosopher Isaac Newton maintained his strong although somewhat unorthodox beliefs.

On the contrary, modern scientists are less religious in comparison to the general population. A prominent exception to this statement is Francis Collins, geneticist and charring the human genome project in the past. In his tome: "The language of God"22 and the Bio Logos Institute he is discussing and supporting compatibility existing among science and Christianity.

It is considered that atheism and agnosticism are prevalent among the scholars, even more, if they are employed in the leading organizations. However, the most recent findings indicate that academics are not opposed to religion and their religious believes are diversified more extensively than publically thought.

Are religious beliefs and scientific views cognitively incompatible-remains still unclear? In contrast to the science which is well-defined from the analytic reasoning style, the religion is driven more by intuitive way of rhinking. ${ }^{23}$

\section{Definition of "Life"}

There is no straightforward reply to the everlasting question: how to define life.

The answer is rather complex and needs a multidisciplinary approach from different fields such as biology, theology, philosophy, sociology, law, and politics.
They all give their view from different perspectives to form a useful answer.

Some authors argue about the existence of life. The "life" that no one has seen it. According to them, the noun "life" is insignificant, there is no such thing as "life", says Szent-Gyorgy. ${ }^{24}$

When trying to define life, we should take into consideration also the facts what life might have been in the past in its primordial form, to the extent of evolution so far today and speculate to what life could develop in the future. What we do know until now mainly thanking an incredible revolution in science, anthropology, and technology. The favorite theory of our universe's origin "The Big Bang theory" focuses on a cosmic cataclysm unmatched in all of history (Origins of the Universe. National Geographic). ${ }^{25}$

According to National Geographic, 25 "this theory reflects the observation that other galaxies are moving away from the Earth at great speed and in all directions as if they had all been propelled by an ancient explosive force. The ancient planet is thought to be about 13 billion years old, and it is the oldest known planet in "The Milky Way". ${ }^{25}$ It is more than twice as old as Earth and a mere billion years younger than the estimated age of the universe. ${ }^{25}$ However, some philosophers debate and argue against this interpretation that the universe has a temporal beginning. ${ }^{26}$

Belgian priest Lemaitrein 1920s suggested first "the big bang theory "wrote" that the universe began from a single primordial atom. ${ }^{25}$ Several questions are still not answered. Why "the big bang" happened? What exactly happened after "the big bang" is still unknown. Scientist proposed and believed that "as time passed and matter cooled, more various diverse kinds of atoms began to form, and they ultimately condensed into the stars and galaxies of our present universe. ${ }^{\text {25 }}$ It is estimated that life as the phenomenon exists on the Earth for approximately 3,5 billion years. ${ }^{25}$ If the life is defined as the continuum, than if one looks at life through the cell itself, than this is true, but if the life is considered as the single human being, than this concept of the life as the continuum is not acceptable and true. $6,8,9,24,27$ The most essential characteristic of living beings is a reproduction, meaning the creation of the new life by transferring the forms of the old life to the new one. But one should be aware that the creation of embryo is not a unique process while genome of the newly formed embryo is unique. ${ }^{25}$ If we look at the creation of life from very beginning that it was the process where chemical matter enables growth of autonomous, self-reproducing and self-regulating structure, which is in fact living, unique and individual being. Individuality is the most important characteristic of new life, which, of course, applies to human mankind and individual human 
beings. ${ }^{29-31}$ From the semantic point of view although every cell of the human body can be considered as life, like for example human placenta, but human life could not be considered as equivalent for a human being. Therefore it is mandatory to make a clear distinction between vegetative human life and "potential individual human life". ${ }^{32}$ From this very short philosophical consideration of human life, it could be concluded that debate on the beginning of human life and its nature should be multidisciplinary with many disciplines to be included and the most important are biology, medicine, ethics, law, theology, religion, anthropology and sociology. ${ }^{28,31,32}$ From the biological point of view, two main cells involved in the creation of human life are spermatozoon and oocyte (Figs 1 and 2). ${ }^{31-37}$ Biologists distinguish the life phenomenon from different points of view, depending on the level of investigation: cell, organism, population or species. ${ }^{31-37}$ Biology as the science provides with the data about the physical development of any life and particularly of human life, but the personhood or personality is not part of the biological scientific approach, but rather should be considered as philosophical issues. ${ }^{37}$ Perinatologists, as scientists and medical doctors, are responsible for intrauterine visualization of early human development almost from the conception, using it for medical and scientific purposes. ${ }^{37}$ Overlapping of biology and perinatology is important for the improvement of knowledge on the beginning of early human development and human life.

\section{FACTS OF HUMAN EMBRYOGENESIS}

From the times of Hippocrates, who described chicken embryo 2600 years ago, and Aristotle who considered wrongly that embryo arose from the menstrual blood and semen 2500 years ago, the embryology as the scientific discipline was born. With the invention of the microscope by Hamm and Leeuwenhoek in the 17th century the spermatozoa were detected, while in the late 18th century Spallanzani understood that oocyte and spermatozoon are necessary to create the human. Schleiden and Schwann in the 19th century launched so-called cell theory saying that embryo develops from the single cell zygote. $^{37,38,42}$

More than a century later Moore ${ }^{42}$ considered the fertilization of the ovum by sperm is the beginning of a development which ends at death. In 2008 he added that development extends into early adulthood and does not end by the birth. ${ }^{39}$

The mystery of the beginning of human life might be hidden in the first 15 days of human embryogenesis, which is the reason to describe this period following the fertilization which is the connection of the oocyte and the spermatozoon, two living cells, which might be considered as the onset of human life. ${ }^{12,28}$

"Human development begins at fertilization when a sperm fuses with an oocyte to form a single cell, the zygote. This highly specialized, totipotent cell (capable of giving rise to any cell type) marks the beginning of each of us as a unique individual." 39

"All of us were once human embryos, so the study of human embryology is the study of our prenatal origins and experiences" (p. 2). ${ }^{40}$

"Fertilization, the uniting of egg and sperm, takes place in the oviduct. After the oocyte finishes meiosis, the paternal and maternal chromosomes come together, resulting in the formation of a zygote containing a single diploid nucleus. Embryonic development is considered to begin at this point" (p.14). ${ }^{40}$

The science is convinced that fertilization is a 24-hour process, beginning with the fusion of the cell membrane of the ovum and the sperm, followed by the first cell division. $^{28}$

That is why the first 24 hours are considered as the period to be investigated for the beginning of human life. Is it single cell embryo - the zygote formed after 24 hours
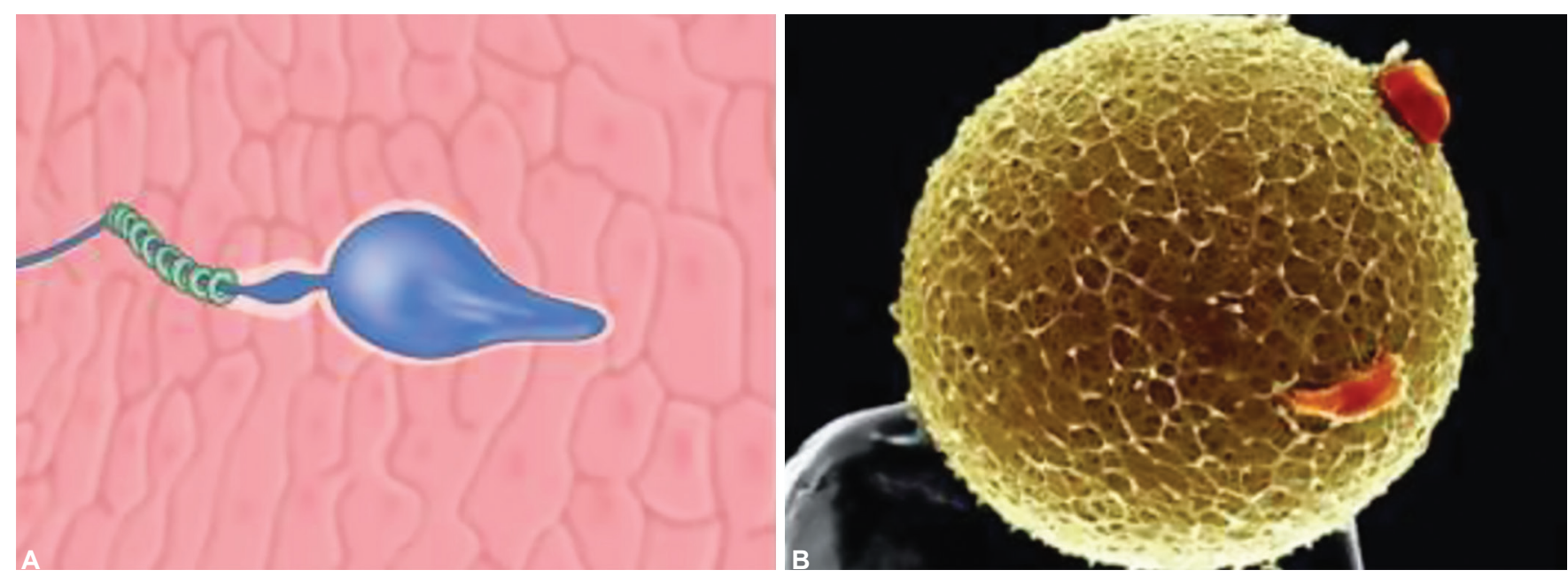

Figs $1 \mathrm{~A}$ and B: Schematic presentation of spermatozoa and oocyte ${ }^{8}$ 


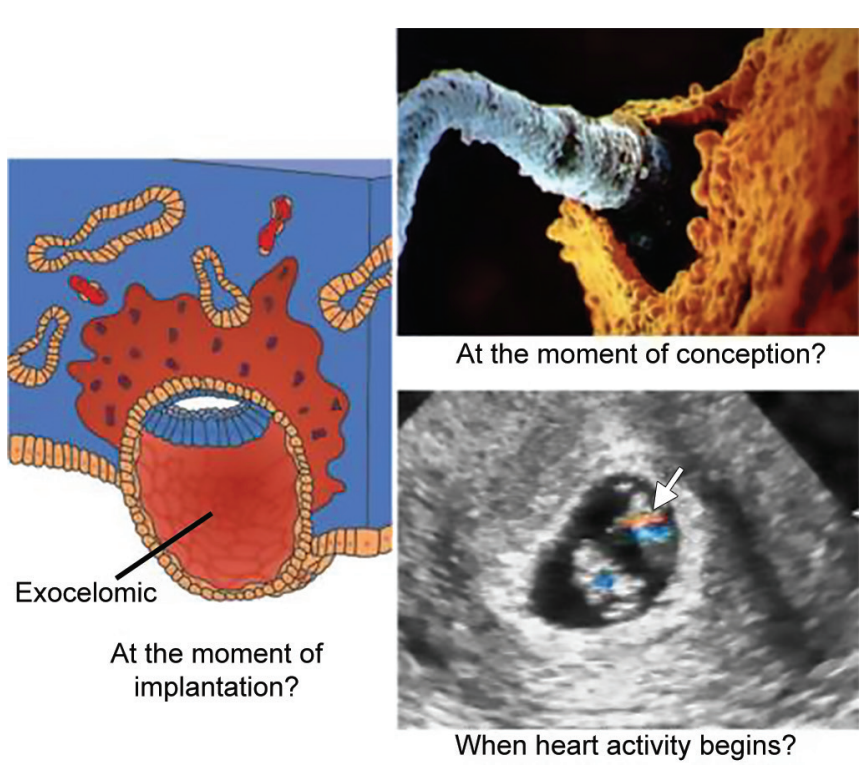

Fig. 2: Some possible questions on the beginning of human life

or maybe is it so called "ovum activation" proceeded with the formation of the zona pellucida and zinc release, disabling more sperms to connect with the surface of the ovum. Successful binding of the cells results in the replication of the DNA, cell division and growth. ${ }^{43}$ This process lasting for 24 hours is called syngamy ${ }^{38,39,46}$ after which the zygote is moving to the fallopian tube undergoing a series of the mitotic cell divisions forming blastomeres, resulting in the formation of the pre-embryo. A blastocyst is then in the process of the attachment to the uterine wall called implantation which is lasting five or more days after the fertilization. ${ }^{47,48}$ At this stage five to six days after fertilization and before implantation so-called preimplantation diagnostic tests are available with the possibility to make the preimplantation diagnosis of some conditions. By the 14 days following implantation all cells of pre-embryo depending on their position will become the part of the placenta, membranes or the embryo. From the 16 days after fertilization till the 8 th week the process of organogenesis is completed and the formation of the embryo is completed. Pre-embryo is the structure lasting from the process of fertilization until the appearance of the single primitive streak. Pre-embryo has the potential to develop in multiple entities, but till the end of implantation, it is not considered embryo, because it lacks genetic material from the maternal mitochondria and maternal and paternal messenger RNA. When considering the rights of pre-embryo as the person, then it should be stated that it is not certain what kind of individual it will become, and whether it will be single or multiple pregnancies, which is the reason why the pre-embryo itself does not have the same moral value as the human person has. It is estimated that three weeks following fertilization after implantation and restriction have completed the genetic uniqueness and singleness are achieved. ${ }^{49,50}$
From the genetic point of view, the newly formed structure has a genome, i.e., nuclear and mitochondrial genome. ${ }^{28,51}$ Genome and epigenome together with the environment are forming a phenotype. ${ }^{5}$

\section{PERSONALITY}

Definition of personality is neither unequivocal nor simple.

One dictionary offers "what constitutes an individual as a distinct person," but does not define "what". Another dictionary declares "the state of existing as a thinking intelligent being." This definition might mislead that personality increases with intelligence. The more acceptable and appropriate definition of personality could be found in Kenneth Stallworthy's manual of psychiatry, stating that"personality is the individual as a whole with everything about him which makes him different from other people." With the next sentence-"personality is determined by what is born in the individual in the first place and by everything which subsequently happens to him in the second." Both parts of the definition can apply to the fetus. ${ }^{31,32}$

Standpoints on the nature of "personhood" and what it means ethically and legally varies widely. According to the Life Protection Act, Sass ${ }^{54}$ existence of the formed synapses without consciousness and self-consciousness cannot be considered as the personhood. ${ }^{54}$ Veatch sees the problem as defining the life that has full moral standing, ${ }^{55}$ while Knutson ${ }^{56}$ has noted that "those who employ spiritual or religious definitions of when life begins to tend to place the beginning of life earlier than those who employ psychological, sociological, or cultural definitions."

"No insignificant person was ever born" meaning that beginning with birth ending on the natural death, from the truism point of view, every human should be valued. Such an approach opens the essential question: "Is the person-unborn a person in the first place and, if so, is the person-unborn a 'significant' person?"31

To evaluate further present controversies, it should be undoubtedly stated that the embryo and fetus in utero are biologically human individuals prior to birth. The fact of being born does not mean that it is a different individual than one staying in the mother's womb. This refers to the term and preterm infants, which means that unborn fetus is a human individual implying a human person in fact, if not in the law. If the brain of the baby is developed to the point where it can show awareness than it can be considered as a human personality. Even if not perfect, like when the fetus is severely malformed, it can be considered as the human individual, because its human nature an functions are preserved and normal. Baby with Down syndrome or open spina bifida or anencephaly or 
only preserved brainstem function should be considered as human individuals even if they survive only for a few hours or days after birth. ${ }^{58,59}$

Does it mean that the definition of the "person" or "human being" includes obligatory easy recognizable signs like laughing, understanding, and speaking, and does the absence of these disqualify one of being a person $?^{31}$ Does it mean that the individual with autism or mutism is less "person"? This leads to the conclusion that it is necessary to establish precise criteria in society and in time to define the "person" (Figs 3 and 4). ${ }^{49}$

\section{EMBRYO AS A PATIENT: BIOETHICAL ELEMENTS TO CONSIDER}

The whole idea of perceiving embryo or fetus as downsized, mini child or adult for that matter is legitimate as
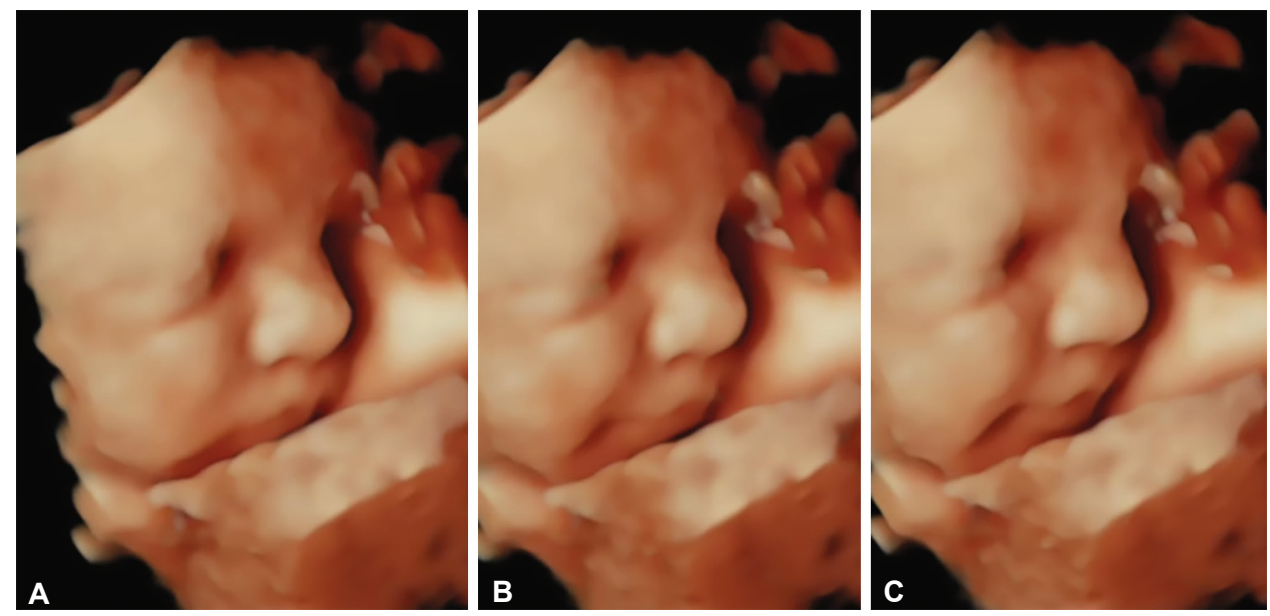

Figs $3 \mathrm{~A}$ to $\mathrm{C}:$ When do we become a person?
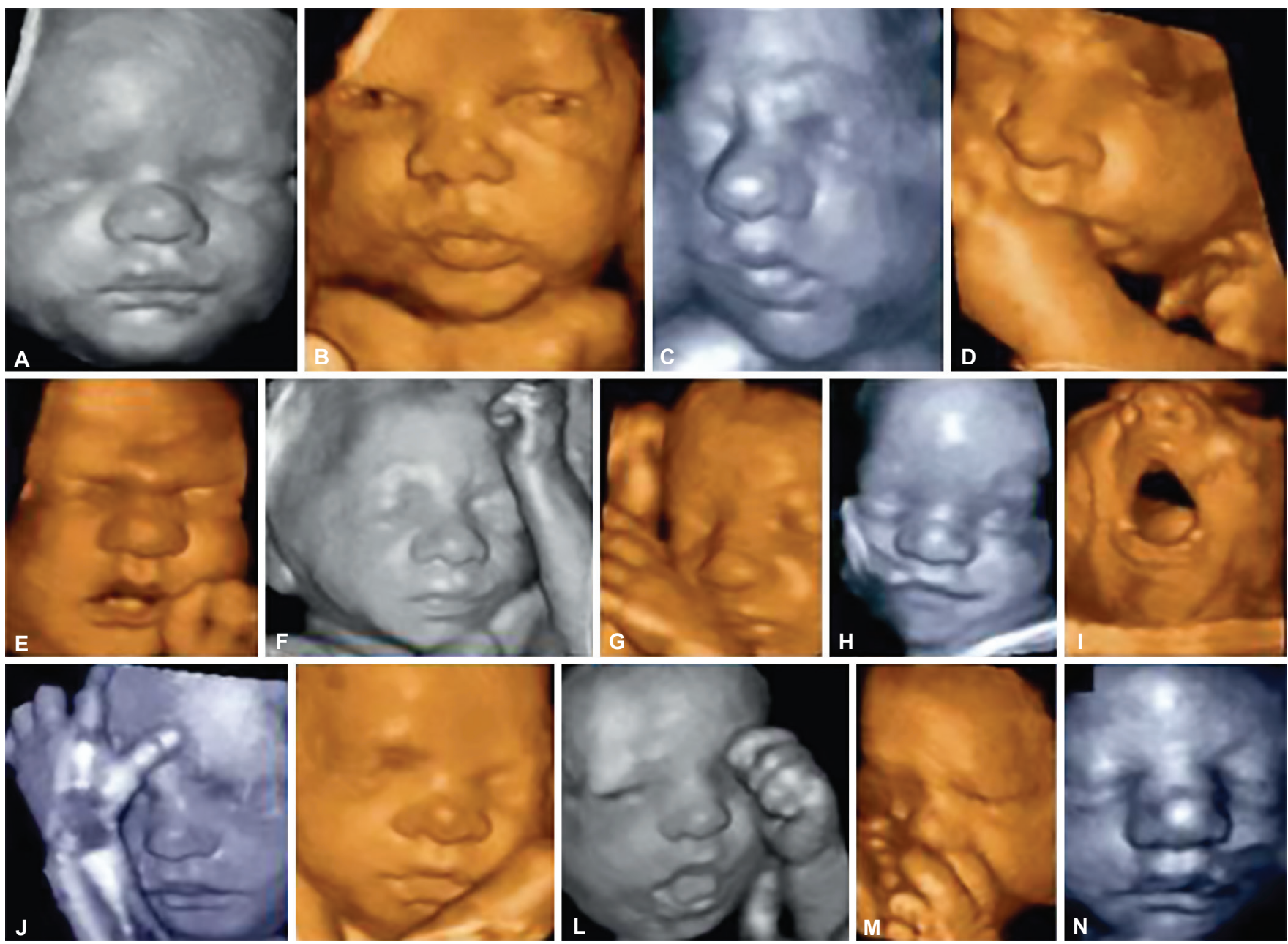

Figs 4A to N: Different behavioral patterns of the fetuses in second half of pregnancy. Are they different personalities? ${ }^{8}$ 
far as an embryologist and fetal physiologist can implement knowledge of all systems after birth. That is, in fact, unreasonable because it does not discriminate certain ways in which the life after birth is fundamentally different from the one before birth. ${ }^{33}$

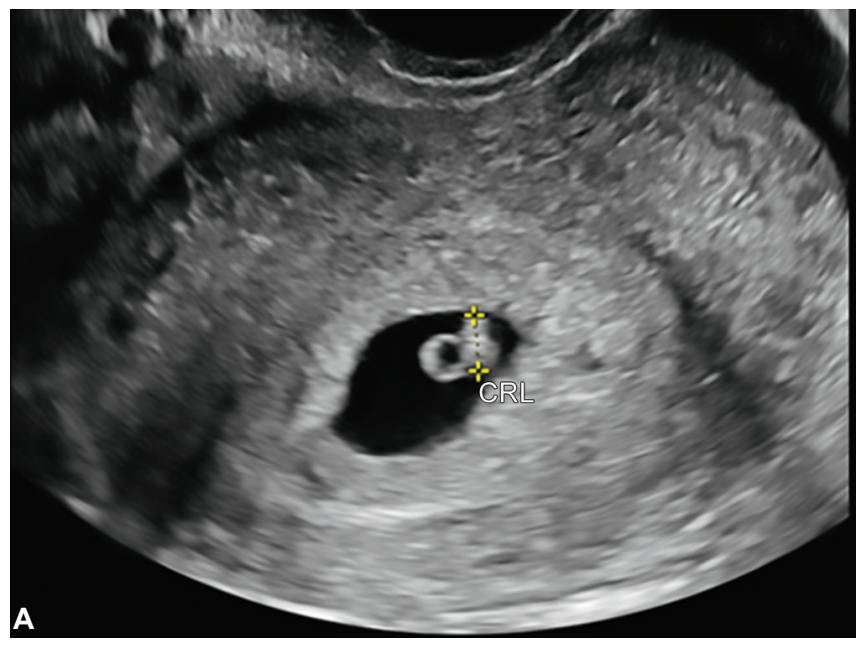

From the biological point of view, the newly conceived structure represents itself as a unique human being that independently and continuously develops due to its inborn drive to procreate an exclusive architecture of its genome 49 (Figs 5 to 10). ${ }^{49}$

Figs 5A and B: (A) Two dimensional (2D) Transvaginal sonography of the 6 weeks embryo with the yolk sac in utero; (B) Three dimensional (3D) transvaginal sonography of the same fetus as in the previous picture. The embryo and the yolk sac are visible
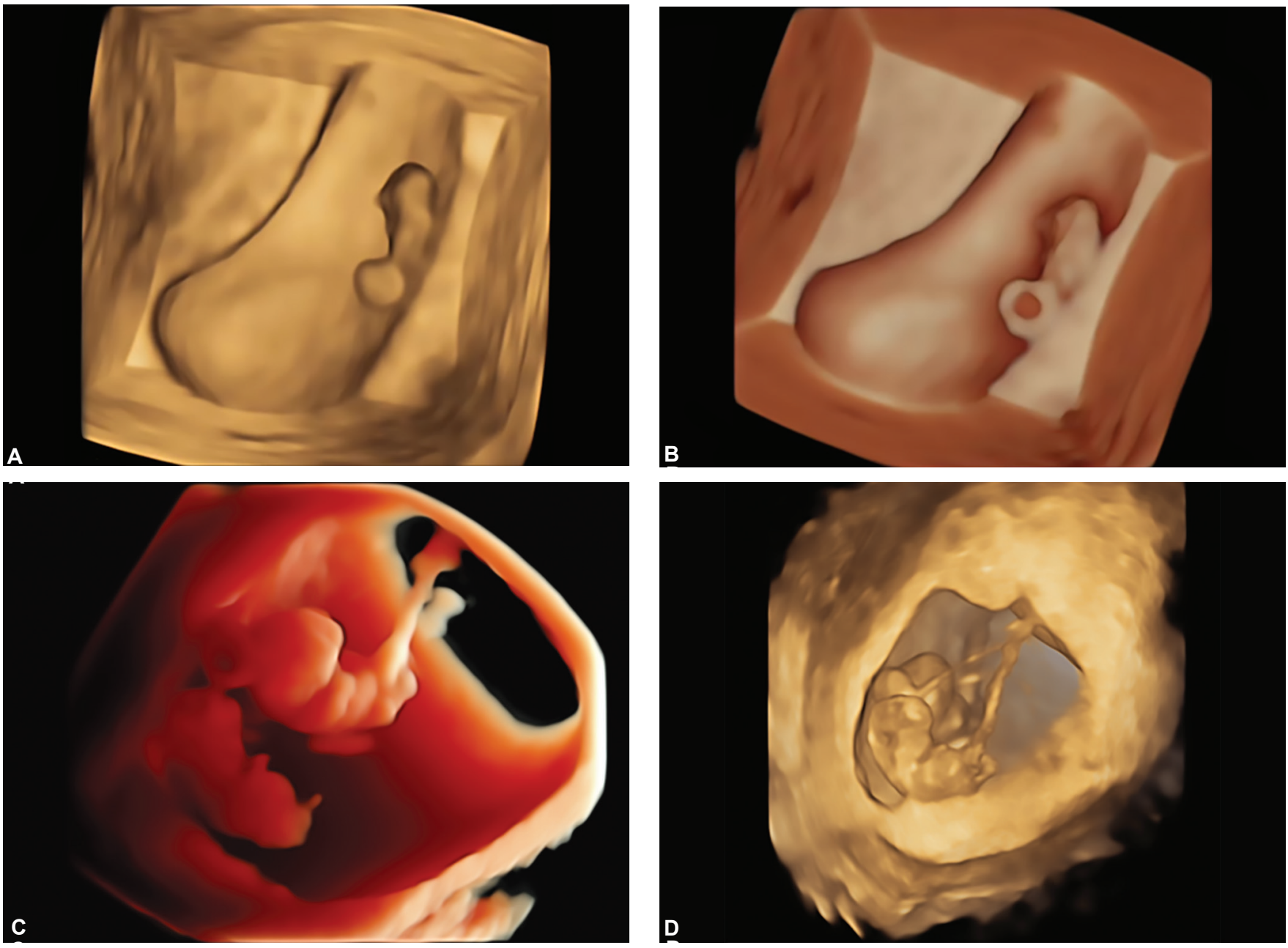

Figs 6 A to D: Seven weeks and 2 days of gestation. With the 3D ultrasound imaging: surface $(A)$ and HDlive (B) rendering modes used to visualize the gastational sac in the utero, within the sac there is embryo and the yolk sac, (C) Nine weeks and four days old twins gestation visualised by 3D HDlive rendering sonography, (D) Nine weeks and four days old twins gestation visualized by 3D surface mode rendering sonography; (notice clearly visable two embryo's, umbilical cords, yolk sac) 
The embryo as a patient "is best explained as a fragment of the bigger concept such as "The fetus as the patient", somehow this path disclosed many ethical problems and dilemmas. As matter of fact, the embryo as the patient is inseparable from its mother and fine balance should be achieved when guarding for the best interest of each of them. Whether or not the embryo and the fetus have autonomous moral

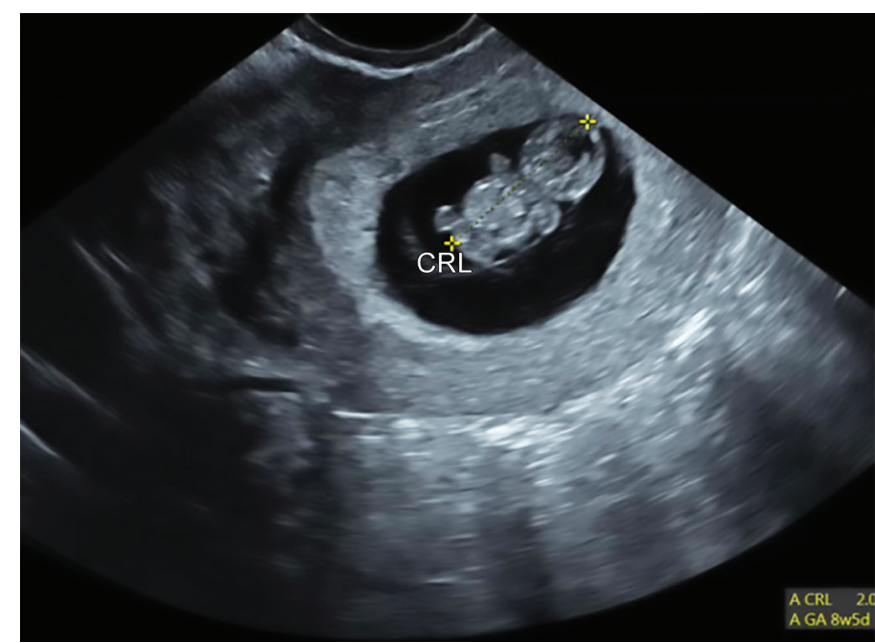

Fig. 7: Two dimensional (2D) Transvaginal sonography of the 8 weeks and 5 days old embryo (almost at the end of the embryonic period); with clerly visable head, body and the limbs. Thiny lines of the amniotic sac are visable around the embryo

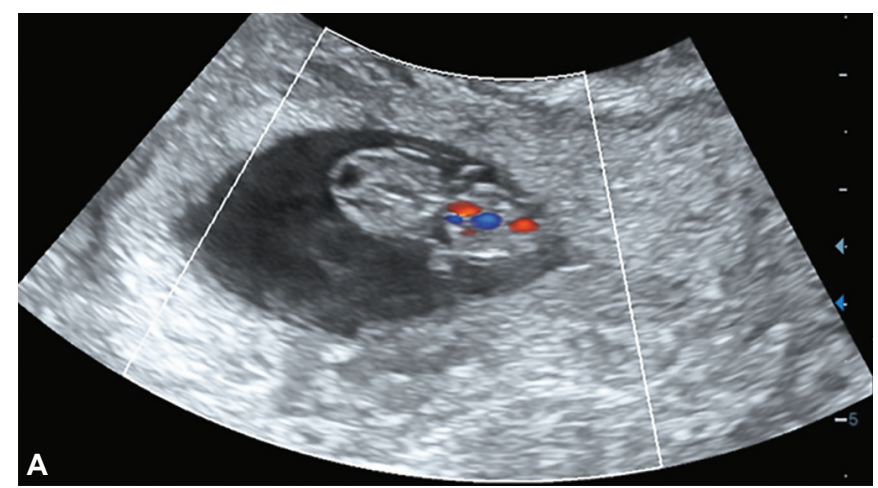

Figs 8A and B: (A) Two-dimensional image with the color Doppler visualization of embryonic circulation at the 7th week of the gestation (B) The same technique used by embryo at the 8 weeks and 5 days of gestation with clerly depicted brain circulation

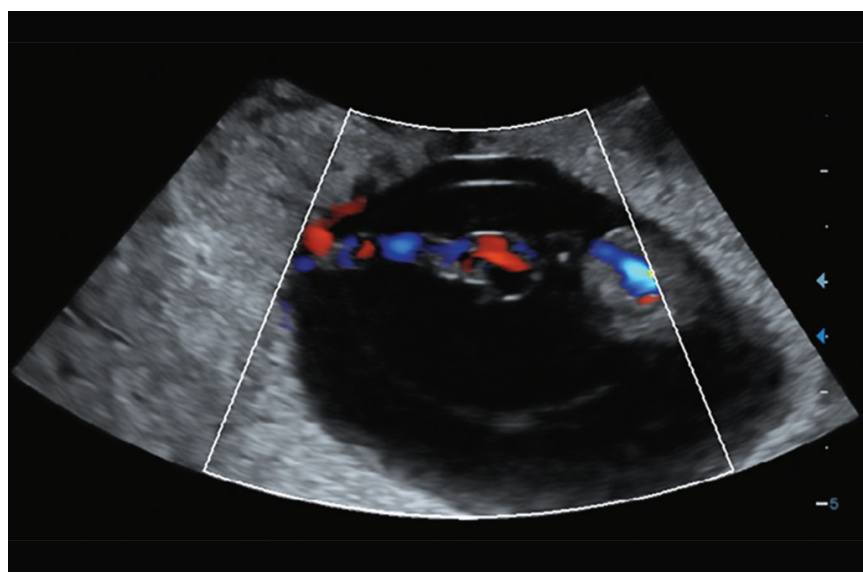

Fig. 9: Early visualization (9 weeks) of the circulation within the umbilical cord conecting the both ends; at the left side is the fetal part and at the right side is the placental side status or personhood, was the subject of many debates. The leading strategy was to disclose the concept of embryo/fetus as a patient. ${ }^{60-62}$ Autonomous moral status for the fetus/embryo would mean that one or more traits they possess (the embryo/fetus itself), regardless and independent of the pregnant woman or any other aspect, result in, and therefore ground obligation to the embryo/fetus apart from the pregnant woman and her doctor.

Fundamental and congenital features such as brief time of conception, implantation, development of CNS (central nervous system), quickening and finally the time of birth have all been taken into consideration. ${ }^{63}$

The intrinsic characteristics like a moment of conception, implantation, central nervous system development, quickening, and the moment of birth have been considered for this role. ${ }^{63}$ If we take into account the various proposed characteristics, there are many opinions about when an embryo/fetus acquire or does not acquire an independent moral status.

There are several views on this matter; one of them is that the embryo/fetus possesses independent, autonomous moral status right from the moment of conception or implantation. With some degree of caution, some
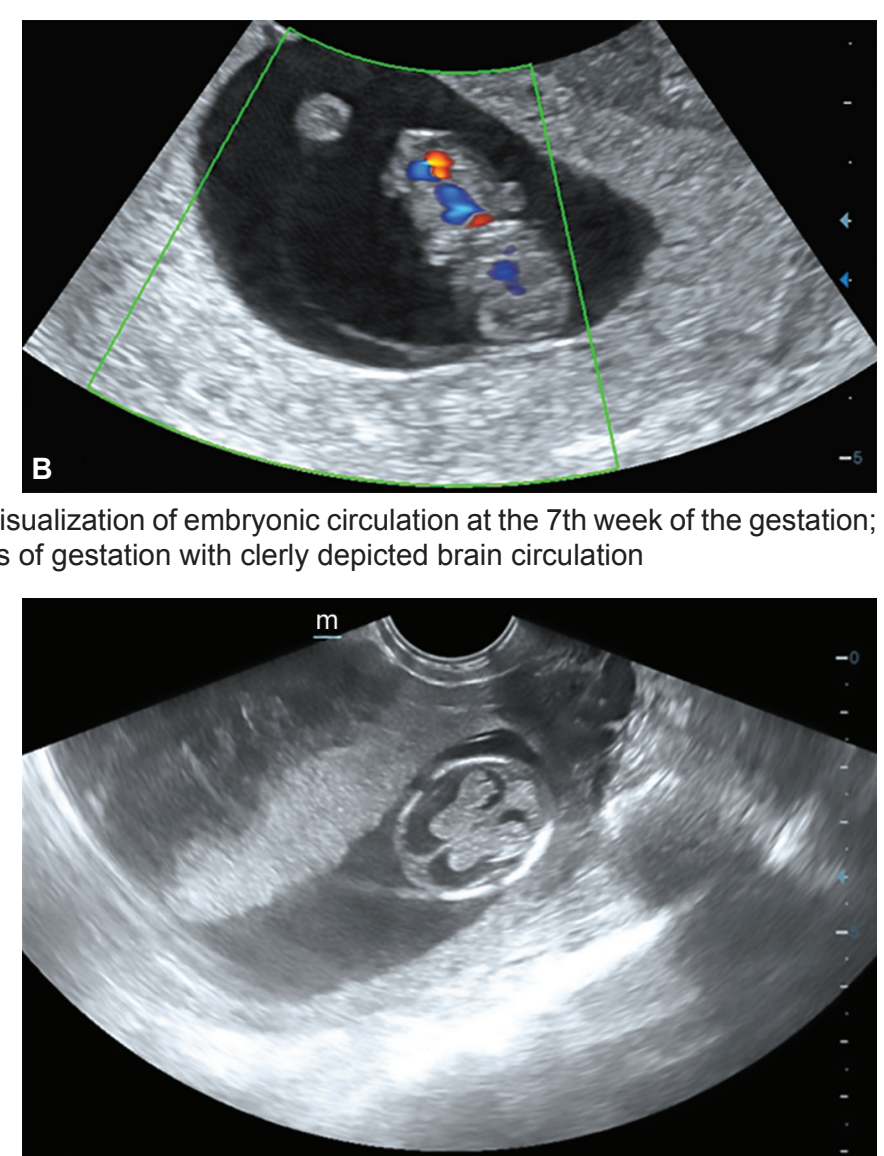

Fig. 10: Two dimensional transvaginal imaging. Axial plane view of the fetal head at the 12 weeks and 5 days, within the scul hyperechoic structure: choroid plexus with typical shape, also called "butterfly sign" 
believe that embryo / fetus gain independent moral status gradually, so-called "graded" moral status. Opposite to both of this, others have a point of view that the embryo/ fetus never gains independent moral status as long as it is in utero. ${ }^{62}$

Being a patient does not necessarily mean or require that someone has an independent moral status. ${ }^{64}$

Being a patient implies that one could profit from the implementation of the clinical skills of the physician and as such some criteria are met. A human being is referred to a physician for the purpose of implementing clinical treatments that are expected to be helpful because they are expected to result in greater benefices than the future harms of the human being. ${ }^{63,65}$

In simple terms, an individual is regarded as a patient when a physician has a beneficence-based ethical responsibility to that individual.

To illustrate the concept of the embryo/fetus as a patient, beneficence-based responsibility is prerequired. Beneficence-based responsibility to the embryo/fetus is present when the fetus can obtain autonomous moral status in the future. ${ }^{65}$

This generates the belief that the ethical importance of the unborn infant is in direct relation with the child to be born.

\section{LEGAL POSITION OF THE EMBRYO}

When debating about the law, it should be beard in mind that medicine is global and universal, but the law is not!

At the time, Aristotle taught that human life begins when the fetus is formed. Before his era beliefs were not in the same line, human life was considered to begin at birth.

Previous to birth, the fetus was considered to be part of the mother, as an organ and not seen as an autonomous, independent human being. ${ }^{66}$ As it has been denoted in the laws of various countries, the moment when the protection of human life should start was at the birth of a full-term baby. In fact, legally speaking, the status of the human embryo is not well defined and depends on the social, political and religious influences in every country.

Surprisingly enough, nearly all Western countries appointed the twelfth week of pregnancy as a legal limit for an abortion. There is no other specific biological phenomenon to rationalize this limit. This is not even the end of the first trimester (thirteen weeks and three days).

So, when should human life be legally protected? By the time of conception, implantation or at the time of birth? It is very difficult to give a straight answer to these questions.

Legal considerations are based on Roman law in most of the countries, with the exception of Ireland and Liechtenstein. Roman civil law declares that "the fetus has rights when it is born or if it is born"-becoming socalled "nasciterus".
Only several countries accept the time of conception as the point of beginning of human personality. The majority does not grant legal status to the human embryo in vitro (i.e., during the 14 days after fertilization). Thus, even in the lack of legal rights, there is no denying that the embryo forms the beginning of human life.

Considering all of this, whatever the viewpoint, each country has to analyses which practices are appropriate with the regard to dignity and the security of human genetic material. ${ }^{67}$

\section{BEGINNING OF HUMAN LIFE AT FERTILIZATION}

\section{Arguments for}

Regarded in as the fundamental statement of biomedical and social (secular) practice is the awareness that the individual before birth is a person and "personhood" is granted by successful fertilization of the egg. Scarpelli stated that it would be unacceptable to hide in silence or ignore that. ${ }^{41}$

So far, it is widely accepted the opinion that human life begins when sperm and egg fuse together to give rise to a single cell called human zygote, whose genetic uniqueness remain unchanged during normal development.

Since the zygote is capable of becoming an adult human individual, it is thought it must be one already. The same zygote arranges itself into an embryo; transforms to a fetus, later grow up as a child and finally become an adult. With due regard, the zygote is a genuine human being (and not only potential one), similarly as an infant is an actual human person with the potential to develop to maturity and not just a potential person. As Scarpelli ${ }^{41}$ pointed out: "outside the realm of religious dogma, there has been no one whose existence can be traced back to any entity other than the fertilized egg." The biological line of the existence of each individual, unexceptionally, begins exactly with the successful fertilization of the egg. ${ }^{41}$

The whole process of fertilization, in fact, starts with the conditioning of the spermatozoon in the male and female reproductive system. Taken this into account, fertilization is not a single event, but rather a complex biochemical operation requiring a minimum of 24 hours to conclude syngamy. Syngamy represents the formation of a diploid set of chromosomes. In the course of this process, there is no fusion of maternal and paternal chromosomes within a single nuclear membrane (prezygote). Sometime after this process, the parental chromosome material is fused (zygote). This new cell has various activities, inter alia; most crucial is the identification of the new genome, which symbolizes the primary data 
center for the development and growth of the new human being and for all its future actions.

There are two main characteristics of the zygote nature that have to be mentioned. The first characteristic: zygote exists and functions from syngamy on as a being, ontologically one, and with an exact identity. The second characteristic: a zygote is intrinsically oriented and determined to a definite development. Identity and orientation of the zygote are both substantially as a result of programmed genetic material with which it is endowed.

On those grounds, this is exactly why many do believe that this cell illustrates the precise moment in time and space where a new human individual launches its own course of life. ${ }^{31}$

\section{Arguments against}

Nowadays, it is generally considered that the human embryo may not be treated as an individual until the fourteenth day after the fertilization, or at least at the point of implantation. Minimally, there are five primary causes in favor of this view:

- Before the creation of the embryonic disk, the embryo is "a mass of cells, genetically human," "a cluster of distinct individual cells," every single one "distinct ontological entities in simple contact with the others". ${ }^{68}$

- A human genome, newly created DNA which is genetically unique, is not set until 48 hours after sperm penetration. The egg and sperm lie side by side for more than 48 hours before ultimate fusion. In biological terms of speaking, this represents conception as a process that emerges over time and not a specific point in time. ${ }^{32}$

- Before the 14th day after fertilization, everything that occurs is purely anticipation and preparation of protective and nutritive systems essential for the future needs of the embryo. At the point when the entity called "embryonic disc" is created, the embryo can further grow into a fetus. ${ }^{69}$

- The "monozygotic twin phenomenon" or chimeras can develop. As a matter of fact, this appears to be the most decisive cause of why the embryo is denied the quality of individuality. This phenomenon is used as proof that the zygote cannot be an ontologically human being. Nearly in $1 / 3$ rd of cases, it splits at about the two cells stage, and in the other $2 / 3 \mathrm{rd}$, the inner cell mass divides within the blastocyst from day 38. Sporadically, separation occurs from day 8 to 12 , but usually, it is incomplete, consequently developing conjoined twins or two-headed individuals. The chimera, resulting from the reincorporation of two individuals to become one individual (and detectable through genetic testing), provides yet another argument against the equivalence of conception and the beginning of human life: "no individual has died, yet one has ceased to exist". ${ }^{62}$
- Coexistence of the embryo and its mother is an obligatory condition for an embryo coming from the human species, this status can be accomplished only at implantation. ${ }^{62}$ Nevertheless, with the rapid development of technology, gaining new knowledge and scientific discoveries we came to the point that there is evidence that development of a human embryo in vitro can continue well beyond the stage of implantation. It is also debated over that so many human embryos die before or after implantation that it would be lacking in realism to accept that the beginning of human individual starts prior to implantation.

It is commonly known that high percentages of oocytes which have been penetrated never continue subsequent development. Many oocytes which do are aborted so early in their development that their presence is not even recognized. Up to $50 \%$ of ovulated eggs and zygotes recovered after operations were found so grossly abnormal that it would be very unlikely that they would result in viable pregnancies. It is also estimated that up to $30 \%$ of conceptions traced by positive reactions to human chorionic gonadotropin (hCG) tests (so-called biochemical pregnancy) abort spontaneously before these pregnancies are even clinically verified. The scientific literature is not unanimous on the incidence of natural wastage prior to, and during, implantation in humans, varying from $15 \%$ to as much as $50 \%$. For the most part, these losses result from chromosomal defects that happened during gametogenesis and fertilization. ${ }^{70}$

Genetic uniqueness and singleness are achieved only after implantation and restriction have been completed (about three weeks post-fertilization). Up until that moment, the zygote and its sequel are in a fluid process, not yet physical individual, and as such cannot be a person. Despite the fact that in a set of twins one individual can vanish ("vanishing twin phenomenon") genetic and individual identities are now more or less equivalent. Some of the eminent Catholic authors, including also Australian priest Norman Ford, author of "When Did I Begin?"75 consider implantation as a symbol of the beginning of human life; they maintain that the pre-embryo has only intrinsic potential and must be protected only from the moment of implantation. ${ }^{71,75}$

- The result of fertilization can be a tumor, a hydatidiform mole, or chorioepithelioma.

Even though the mole is alive and of human origin, it is certainly not a human individual or human being. It is missing a true human nature from the start and has no natural potential to begin human development. Another example is a teratoma, cells developing abnormally from the product of fertilization. It has no potential to develop into fetus or infant and cannot be considered to be a true human individual with human nature. This should be clearly distinguished from the case of the fetus with the 
teratoma that would be a human individual, but not the attached teratoma itself. Obviously, not all the living cells that arise from the conceptus, early embryo or the fetus create an integral part of a developing human individual. ${ }^{31}$

\section{DIVERSE RELIGIOUS TEACHINGS AND HISTORICAL ASPECTS}

The Catholic Church's teachings are defined well in the introduction Donum Vitae: "A human creature is to be respected and treated as a person from conception and therefore from that same time his (her) rights as a person must be recognized, among which in the first place is the invaluable right to life of each innocent human creature." $72-74$

In 1997, the 3rd Assembly of the Pontifical Academy for Life was held in Vatican City. It has been drowning conclusion that "at the fusion of two gametes, a new real human individual initiates its existence, or life cycle, during which-given all the necessary and sufficient conditions - it will autonomously realize all the potentialities with which he is intrinsically endowed." From the time the gametes fuse, the embryo is, therefore, a real human individual and not a potential human individual. It was added to the statement that recent findings of human biological science acknowledge that in zygotes arising from fertilization, the biological identity of a unique human individual is formerly established. ${ }^{72,73}$

In North and South America and Western Europe, these standpoints are mainly founded on Judeo-Christian theology. The Islamic and Buddhist religions have influenced and predominate in Arabian countries as well as in Asia and Africa. Nevertheless, their approach on the beginning and creation of human life is remarkably alike; each of these religions has distinct attitudes towards the problem of embryo research, infertility, and its therapy.

The Jewish attitude towards infertility is expressed in the Talmud sayings and the Bible (incorporated in the 1st commandment of God to Adam "Be fruitful and multiply"). Christian views are definitely geared towards encouraging the creation of a new life but also the preservation of the existing one. Realization of parenting at all costs is not seen as the right path to do. The Christian perspective states no absolute right to parenthood. According to the Islamic point of views, giving efforts to cure infertility are seen also as one's responsibility.

Islamic teaching is founded on prophet Mohammed statement: The creation of each of you in his mother's abdomen assumes a "nufta" (male and female semen drops) for 40 days, then becomes "alaga" for the same (duration), then a "mudgha" (like a chewed piece of meat) for the same, then God sends an angel to it with instructions. The angel is ordered to write the "Sustenance", life span, deeds and whether eventually, his lot is happiness or misery, then "to blow the Spirit into him" (Human developments as described in Khur'an and "sunnah"; (Moore, et al. In: Some evidence for the truth of Islam; 1981). The summary of this poetic and sacred description is: Soul breathing "ensoulment" occurs at 120 days of gestation counted from conception.

Islamic Jurisprudence Council wrote a Fatwa in 1990. To make these religious principles applicable to everyday practice. In Fatwa it is written: "Abortion is allowed in the first 120 days of conception if it is proven beyond doubt that the fetus is affected with a severe malformation that is not amenable to therapy, and if his life, after being born, will be a means of misery to both him and his family, and his parents agree." According to this, it would be no difficulty for either the antenatal diagnostic procedures or for the potential termination of pregnancy within the bounds of Fatwa.

In Buddhism, there are strict rules and ethics for priests, but the attitude towards the laity is quite mild and tolerant. It is considered that if there is a medical procedure or infertility treatment, people should use it.

The views of Aristotle, a great Greek naturalist, and philosopher about the beginning of human life have been used for more than 2,000 years. It was thought that male sperm, the so-called "pneuma", has the special power to turn menstrual blood first into a living being with a vegetative soul after 7 days and then into one with a sensitive soul 40 days after contact with a man's semen. ${ }^{74}$

Akvinas fully accepted Aristotle's theory, but he accurately specified what and when it happened. Namely, he believed that the "ensoulment" is God's act that turns a living being into a human being after he has acquired the delicate soul. The first 7 days were the time of conception, and the complete formation of living beings and transformation into human beings lasted for 40 days. $^{75}$

The standpoint of Hippocrates has been significantly improved as opposed to what was schematically written in "the Book of Leviticus". ${ }^{76}$ Namely, he believed that the entry of a soul (ensoulment) into a male embryo occurred on the 30th day of intrauterine life, and in a female embryo on the 40th day. In the previous records, it was scripted that the soul does not enter the female embryo until 40 days after the conception. ${ }^{76}$ In conclusion, the act of ensoulment allows the matter to transform into a human being and become a person.

In 1633, Harvey went on further researching the deer to prove that Aristotle's theory of human reproduction was inaccurate. At the same time, he could not find acceptable clarification about human conception.

More recently, after modern scientists discovered the process of fertilization, most people assumed that human 
beings, along with an ensoulment, began at the point of fertilization.

There is no straightforward answer to the question "When has the human being come to life?". To answer this properly, one should merge the knowledge of various religions, different philosophies, and several biological science disciplines. The philosophical views and principles of each individual determine the already narrow boundary between the expertise of science and metaphysics. These two autonomous disciplines have often tried to overcome, dominate, and even ignore one another.

Not so long ago, several theologians and most of the scientist became aware of the fact that the different religious and scientific views and "truths" are genuinely complementary and methodologically autonomous. The contemporary science is interested in explaining the concept of nature by studying and explaining through the facts, instead of inventing it. This is also the main difference between these two disciplines. Scientific "truths" have to be experimentally verified, so-called "evidence-based". This knowledge can be verified, explained and learned.

While science prefers a rational approach to important issues, religion often prefers the irrational one. Scientifically presented, intellectual knowledge is mostly expressed quantitatively in the form of mathematical formulas, whereas, contrary to that, religion prefers to present its perceptions qualitatively in the form of metaphorical expressions.

Currently, there is a tendency, even on the higher instances to renew the dialogue between the two. The "Religion" existed long before science came to light, but in spite of this, it is not necessary to think that science is the continuation of religion.

Science and religion each have their own beliefs, understanding, and conclusions. Nevertheless, all of these distinct components are part of one unique culture of mankind.

\section{CLINICAL DISPUTES}

Starting a conversation at the beginning of human life, there are always represented some important clinical issues and controversies.

With the evident proof of motility, provided by an efficient device for motion in the form of whipping tail, spermatozoa are very much seen as living cells. Manufactured in the testicles, these cells need to go a long way before being capable of fertilization. Their activation starts in the male and continues in the female reproductive tract where spermatozoa gain the capacity to fertilize the egg.

Whether the spermatozoon is a being or not (i.e., alive and human with the ability for continuous life once fertilization has happened)the decision must be made.
Although in another form, it is entitled to " the right of protection as a person".

There are those who deny the right to life (to spermatozoon) claiming it's not a whole cell because it includes an only haploid number of chromosomes. Ironically enough, this would mean that "definition of human life" is made purely in regard to number of chromosomes in a certain cell and would have far-reaching effect and consequences, as pointed out by Mastroianni. ${ }^{77}$ Nonetheless, "an individual born with fewer or more chromosomes than normal is human and entitled to all the rights of personhood."

We could claim that life begins when brain activity is generated and opposite to this, ends by the cessation of the same. If considering the beginning and termination of human life in that way, one would admit that the interpretation of " the beginning of life" is dependent on technology and not on morality or ethics. Others implied that the beginning of human life was obtained by the neural fusion of the periphery with the center and adequate maturation of the brain. ${ }^{78}$

Allegedly, there is a symmetry concept "if the death of a human being requires the death of the brain, the beginning of human life shall correspond with the beginning of the life of the brain, considered to be at day 32 post-conception (PC)" as formulated by Brody. ${ }^{79}$ On the other hand Sass ${ }^{81}$ accurately pointed out the fact that fusion is not established anatomically without neurons which form synapses, which would be at approximately 70 days ( 8 weeks) pc. ${ }^{80}$

From this perspective, one could look into another example such as the definition of birth which was, some years ago, specified as "the complete expulsion of a fetus of $1000 \mathrm{~g}$ or 28 weeks of pregnancy". However, some years later, advancements of perinatal and NICUs (neonatal intensive care units), shifted the line at $500 \mathrm{~g}$ or nearly at 22 weeks of gestation. The illogical nature of such definitions led to consequences of this definition such as that, for example, 20-week old fetus even if viable, was not considered born. Fortunately, this thesis has changed. We can go on with the same logic and state that life begins with the sonographic proof of the heartbeat. However, this limit would change on a yearly basis as the technology, science and our skills to detected heartbeat improve. To pursue this argument means to give life, birth, and viability definitions specified by technology. It can be concluded, seen from the technological perspective, the more advanced the technology, the earlier life begins. Complete absurdity.

Giving thought about the beginning of human life, we must consider the fact that there is also the end of human life that must be equally defined.

Allow us to reflect on the following a few-weeksold newborn is admitted to the hospital with massive traumatic brain damage after a horrible car accident. 
Regardless of all measures, no brain activity is found in the course of a few days later and the baby is declared dead. Various body parts and organs could live on long after its death, as after the death of any person of whatever age. Nails and hair can grow for days. Some organs like kidneys, liver, heart, etc. can be transplanted into another individual and may go on living for years. If, shortly after death, cells taken up and cultured in the lab, the cells could live very long, even though the life of this child has ended. To draw the conclusion in this case and generally accepted by the public, courts, and physicians is that death of the brain implies the end of life. ${ }^{33}$

Let us come back to the query of when life begins. The DNA of the fertilized ovum (egg) has the data required to create an individual, but so does practically any other cell in the body. No one would demand the rights for living cells of the infant from the accident, though each cell has a complete set of DNA. The same applies to many living cells of the skin that we lose each day when we wash our hands.

So, this brings us to the conclusion that there are so many questions still to be answered and there are no straightforward answers.

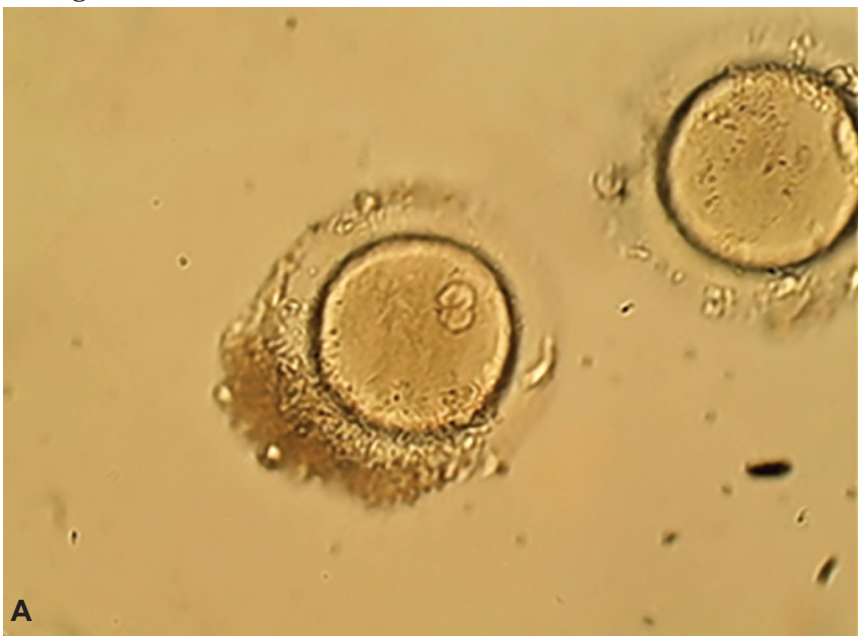

\section{EARLY HUMAN DEVELOPMENT-VISUALIZED BY ULTRASOUND}

Owing to the launching of new technologies, such as threedimensional (3D), color Doppler and four-dimensional (4D) sonography, etc., great improvements have been achieved in the visualization capabilities and assessment of early human development. Asignificant amount of biochemical, morphological and vascular alterations that appear inside the follicle now can be studied. The course of ovulation and luteinization can be assessed by transvaginal sonography (TVS) with color Doppler (CD) and different 3D render modes. ${ }^{81}$

During the precise timeline after the fertilization, the embryo is transported to the uterine cavity where under the optimal hormonal and environmental conditions, it will further be embed and grow into a new and unique individual. A detailed assessment of vessels such as arteries supplying preovulatory follicle, corpus luteum and endometrium was not possible before the introduction of TVS and CD. ${ }^{69}$ The 3D TVS enables precise and detailed morphological survey of the follicles and visualization of cumulus oophorus if any. Follicles lacking cumulus are unlikely to contain fertilizable oocytes. Information like this is essential in the assessment and treatment in patients subjected to ovulation induction (Fig. 11).

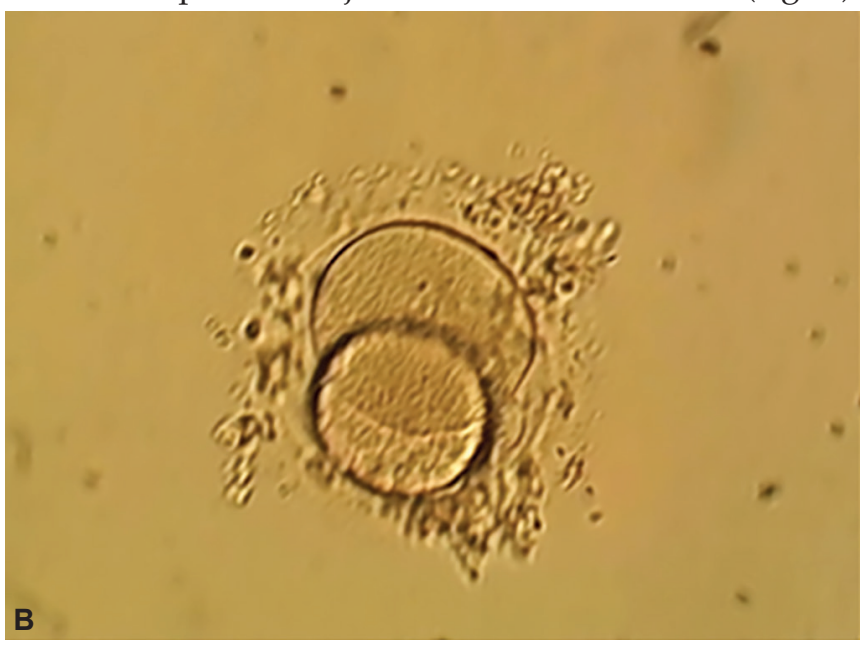

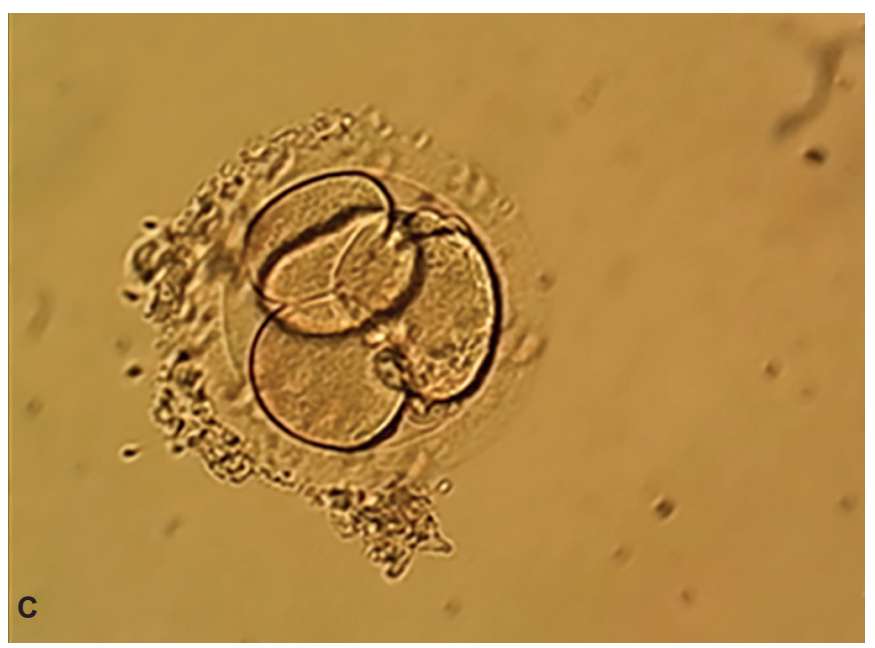

Figs 11A to C: (A) Left: fertilized oocyte = zygote, and right: unfertilized oocyte; (B) 2-cell stage; (C) 4-cell stage (Courtesy: Tinjic S) 
After the ovulation and as the result of diverse structural, functional and vascular modifications in the former follicular wall, corpus luteum is formed. Blood flow velocities assessed by TVS and CD enable evaluation of the corpus luteum function in the 2nd phase of the menstrual cycle and earliest pregnancy. The regression of corpus luteum begins as soon as the placenta takes over the main production of progesterone.

Maximal endometrial receptivity is present only a brief time after the ovulation takes place. During this time, within a few days, a blastocyst can attach to the endometrium and stimulate amplified vascular permeability together with vasodilatation at the implantation location. Specific proteolytic enzymes produced by trophoblast, erode neighboring maternal capillaries and induce the penetration of the uterine mucosa.

The consequence of this is the creation of the intercommunicating lacunar network, so called-placental intervillous space. Within the period of 32-34 days of gestation, small intradecidual gestational sac can be visualized by transvaginal sonography (TVS) (Fig.12). ${ }^{82}$

At the start of the 5th week of gestation, the secondary yolk sac (YS) is normally seen within the gestational

sac as the earliest extra embryonic structure. The volume of the yolk sac gradually magnifies from 5th to 10th gestational weeks (gw). By the time that YS gains its maximum volume at approximately 10th gw., it already started to deteriorate. This could be seen as a reduction in displaying the vascularity of the YS by TVS+CD. ${ }^{68}$ Synthesis of the knowledge gained by the functional and volumetric 3D power Doppler studies helps identify some of the most crucial events in early human development.

By accepting blood components from the yolk sac and pushing blood into the circulation, the embryonic heart begins beating on about day $22-23$, so that the blood starts circulating at the end of the 4 th $\mathrm{gw}$ of development. The embryo-chorionic circulation alters the origin of nutrition to all intraembryonic tissues. Continued growth and development of the embryo demand better circulation and blood supply of embryonic/fetal blood required to stay alive. Neither the embryo nor the placenta (chorion) can survive one without the other.

Inside the embryo, we recognize 3 separate blood circulatory systems: ${ }^{48}$
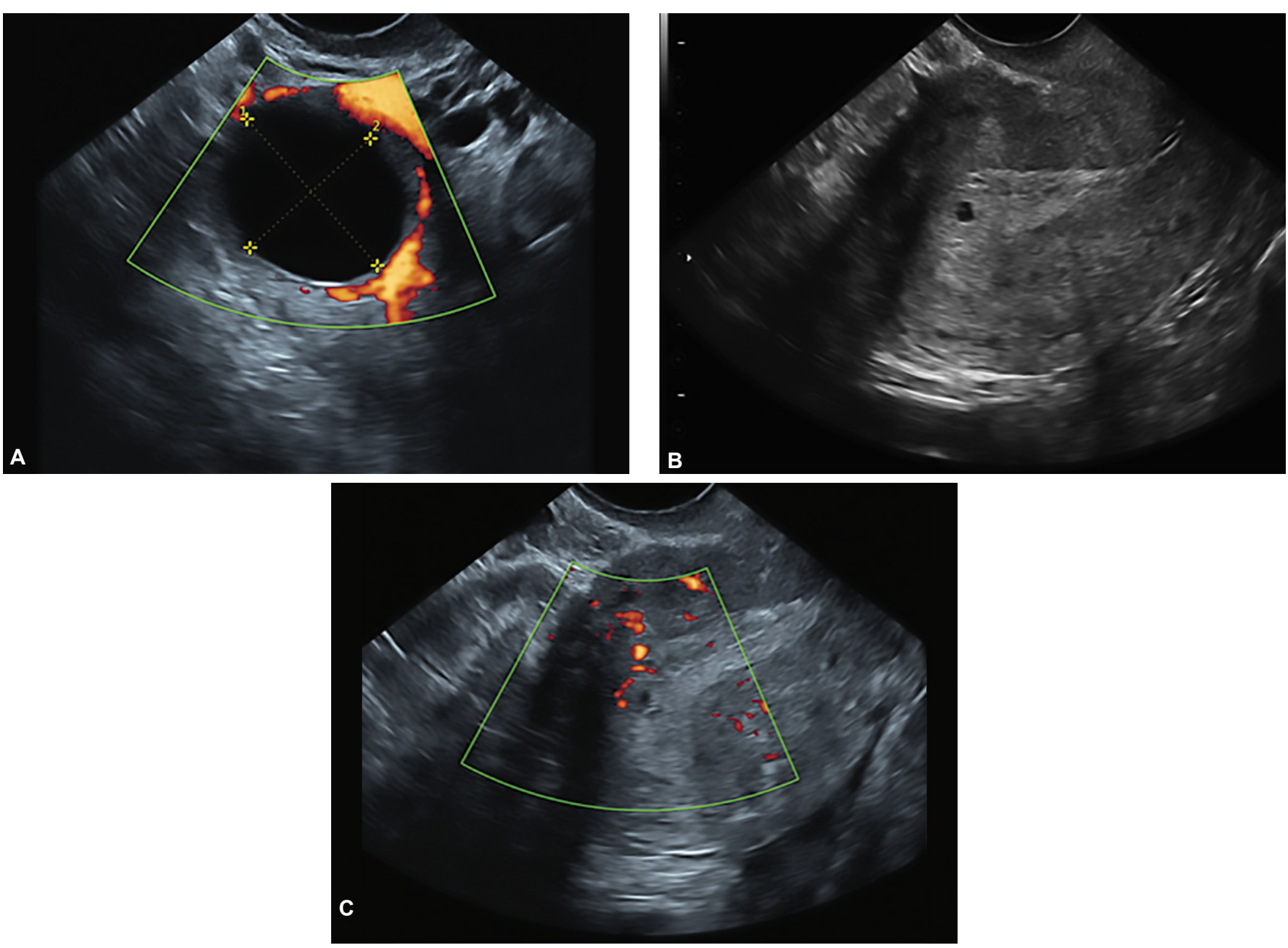

Figs 12A to C: (A) Corpus luteum; (B) A small intradecidual gestational sac can be visualized by transvaginal sonography between 32 and 34 days; (C) During these few days, a blastocyst can attach to the endometrium and provoke increased vascular permeability and vasodilatation at the implantation site 
- Vitelline circulation (YS to embryo)

- Intraembryonic circulation (Figs 8 and 9)

- 2 umbilical arteries (embryo-placenta = fetoplacental circulation) (Fig. 9).

This can be easily seen by TVS+CD from the conception. ${ }^{83-87}$

Around 5th gw, from the maternal side of placenta: developing intervillous circulation during the 1sttrimester of pregnancy by 3D TVS. The 3D power Doppler discloses profound vascular activity enclosing the chorionic shell: first sonographic confirmation of the growing pregnancy in the course of the 5th gw.

At 7th gw, 3D power Doppler depict aortic and umbilical blood flow.

From 8th-9th gw, the fast-growing intestine is being herniated into the proximal umbilical cord (physiologic umbilical hernia) this is a normal finding.

During 9th to 10th gw, herniation of the mid-gut may be present. The arms, elbows and legs, knees are visible, as well as feet that are approaching the midline (Fig. 13).

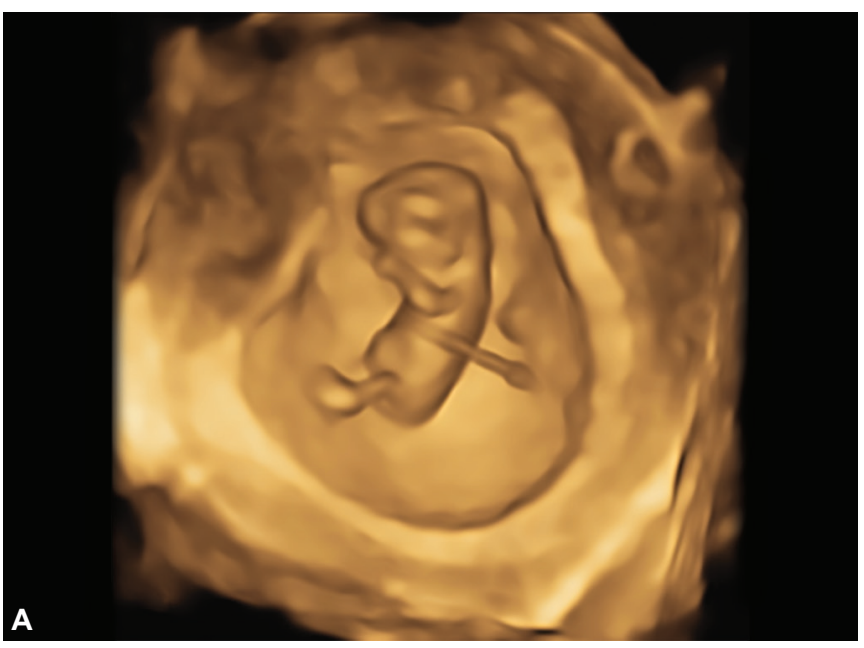

At 11 weeks, 3D power Doppler assessment: visualization of the entire fetoplacental circulation (Fig. 14).

Around the 11th to 12th gw, the growth of the head/ neck continues. Facial details are visible: nose, orbits, maxilla, and mandibles (Figs 15 and 16). Herniated mid-gut already returned into the abdominal cavity, if not it is considered as pathological and further investigation is needed.

\section{CONTEMPORARY OPTIONS FOR PURSUING EMBRYONIC MOVEMENTS AND BEHAVIOR}

Modern technology that includes the 3D/4D sonography permits the explicit study of embryonic to fetal movement and behavior (Fig. 17). ${ }^{88-113}$ With $4 \mathrm{D}$ ultrasound, movements of the entire body and different parts can be seen synchronously in 3 dimensions..$^{89-90,93-114}$ It is obvious that neurological development-early fetal motor activity and behavior- needs to be reviewed by this novel technique. ${ }^{86-113}$

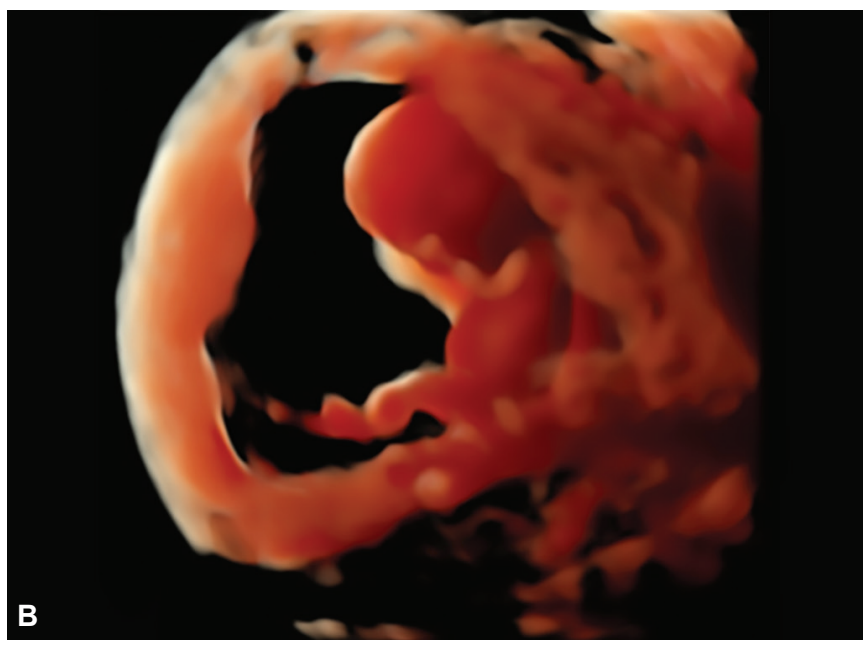

Figs 13A and B: (A) Ten weeks and 4 days fetus, 3D surface rendering, notice the arms with elbow and legs with knee are clearly visible as well as feet; (B) The same fetus in 3D HDlive rendering

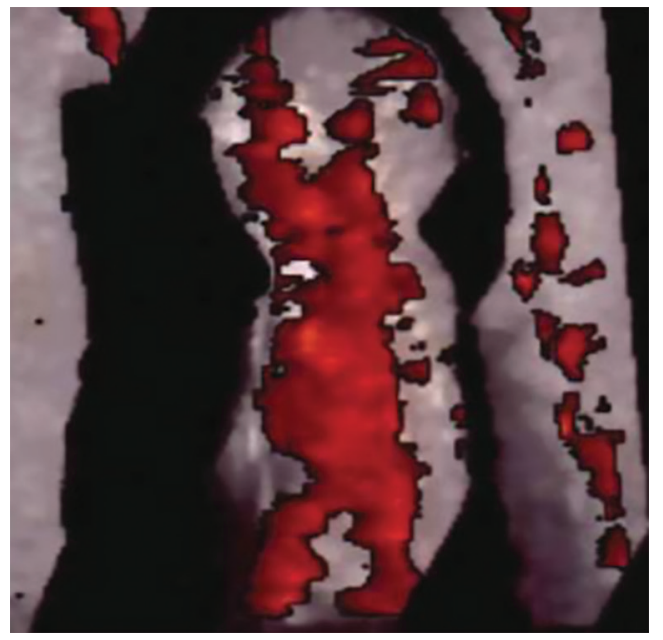

Fig. 14: A 14 weeks fetus. Complete visualization of fetal and placental circulation shown by 3D power Doppler ${ }^{8}$
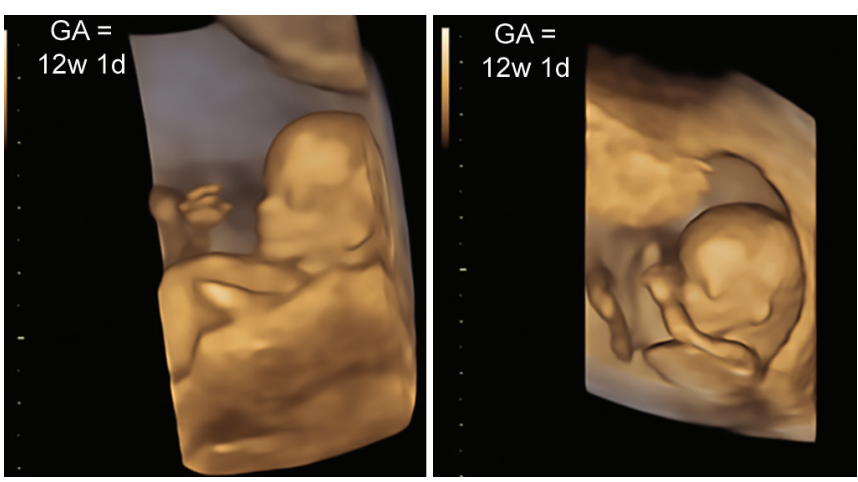

Fig. 15: Fetus at the 12 weeks of gestation. Imaging: 3D surface mode. Facial details such as nose, orbits, maxilla and mandibles are clearly visualized 
Our group evaluated the development of the complexity of spontaneous embryonic and fetal movements. ${ }^{93}$ The complexity of the movement's increases with the advancing gestational age. The increasing number of axodendritic and axosomatic synapses from 8 th to 10 th, and again 12 th to 15 th $\mathrm{gw}^{94}$ correlates with the time of fetal movement diferentiation and with the onset of general movements and complex activity patterns, such as stretching, swallowing and yawning, seen easily by $4 \mathrm{D}$ technique.

During 7th to 8th gw, gross body movements emerge seen as changing of the position of the head towards the body. Around 9th-10th gw, imminent limb movements consist of changing the position of the extremities toward the body without the extension or flexion in elbow and knee. From 10 to $12 \mathrm{gw}$, the rising number of complex limb movements can be studied. They consist of extension and flexion in the elbow and knee (Figs 13 and 15 to 17).

Between 12gw and 15gw, Skill set increases by the appearance of stretching swallowing and yawning. In addition, it is now feasible to study by $4 \mathrm{D}$ ultrasound a full range of facial expression including smiling, crying and eyelid movements (Fig. 15).

Latest 4D ultrasound technology with all additional equipment will improve the understanding of both somatic/motoric development of the embryo/fetus. It will also enable the reliable study of fetal and even parental behavior (Figs 18 and 19). ${ }^{89-113}$

There was recently a number of papers published on new attractive techniques for visualization of early human development.
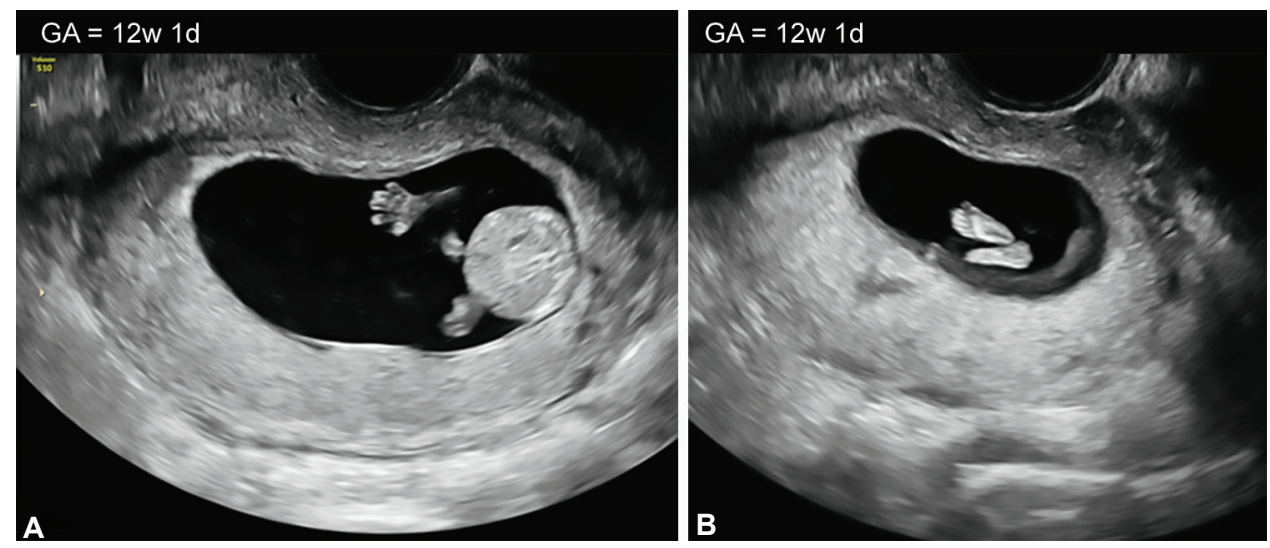

Figs $16 \mathrm{~A}$ and $\mathrm{B}$ : With $2 \mathrm{D}$ imaging, visualization of the fetal fingers and toes at the 12 weeks and 1 day
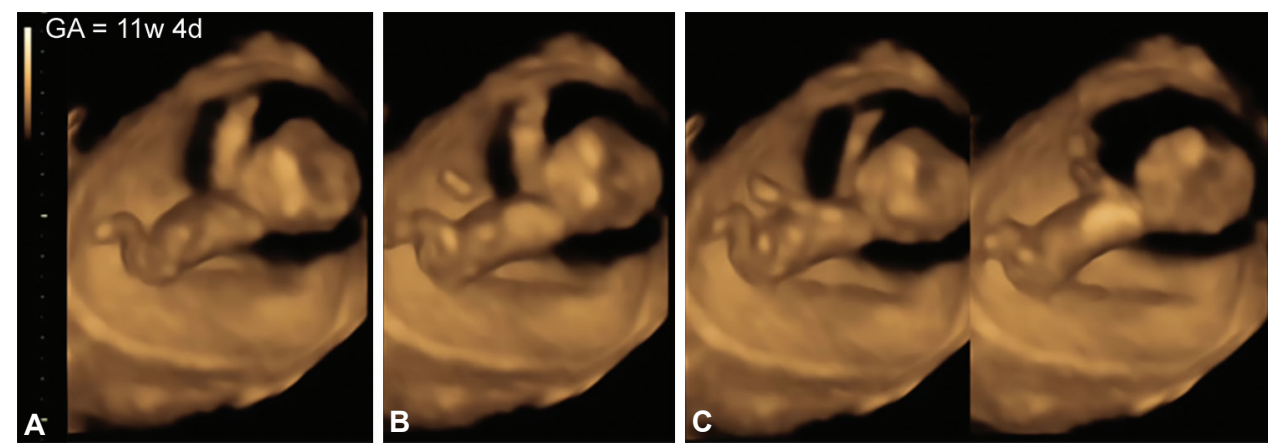

Figs 17A to C: 3D and 4D sonography enables precise study of fetal activity and behavior at 11 weeks and 4 days at the presented sequence of ultrasound images

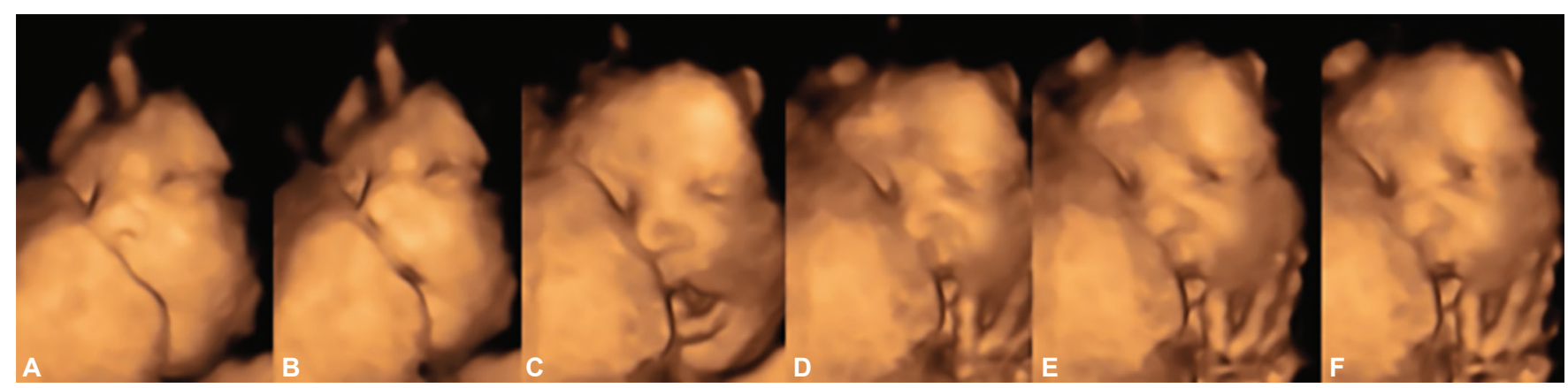

Figs 18A to F: Sequence of images recorded with the 4D ultrasound, surface mode. Fetus at 33 weeks of pregnancy, KANET test was performed (Kurjak Antenatal Neurodevelopmental Test). Notice how fetus explores the environment with the mouth, by the hand and with the eyes 


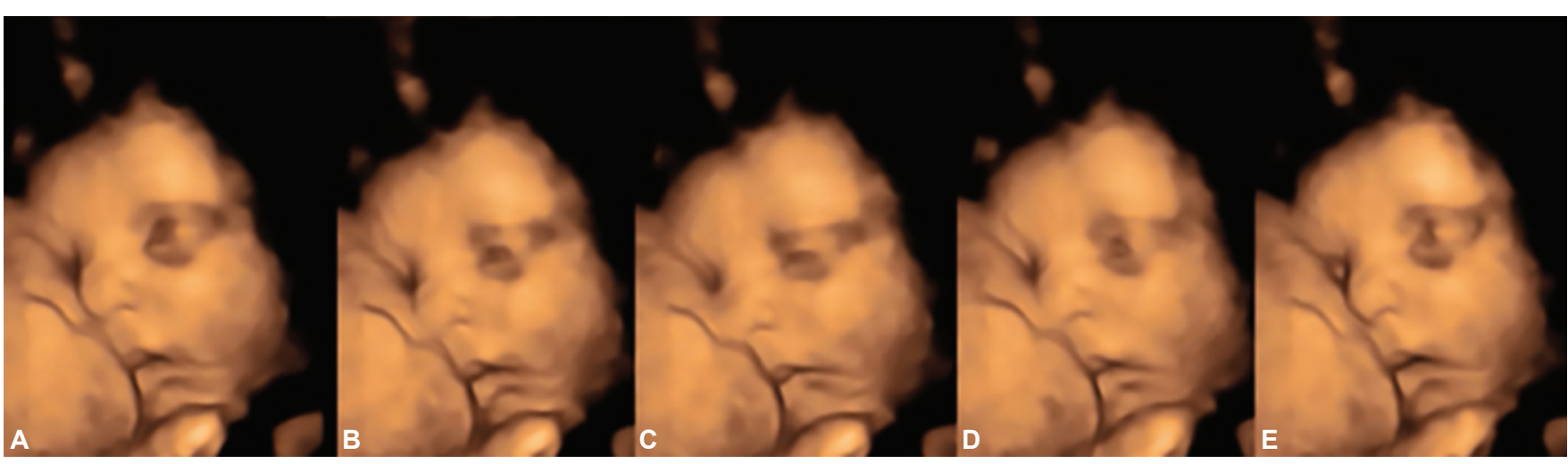

Figs 19A to E: The same fetus as in Figure18, looking around in utero, exploring the environment

\section{CONCLUSION}

Everlasting rhetorical questions: when human life begins and how we may define it could be explained only combining the interconnecting paths of history, medical science philosophy, and religion. It has been hard to decide where to draw the line between the expertise of science and metaphysics in this delicate interdisciplinary field. The fundamental philosophical vision largely determines the boundaries of these lines.

- Quoting Beller: "The point at which human life begins will always be seen differently by different individuals, groups, cultures, and religious faiths. In a democracy, there are always at least two sides, and the center holds only when the majority realizes that without a minority, democracy itself is lost. The minority, in turn, must realize its best chance lies in persuasion by reason and thoughtfulness rather than fanaticism." ${ }^{32}$

\section{REFERENCES}

1. Stenmark, Mikael. How to Relate Science and Religion: A Multidimensional Model. Grand Rapids, Mich.: W.B. Eerdmans Pub. Co.; 2004.

2. Harrison, Peter. The Territories of Science and Religion. University of Chicago Press; 2015.

3. Cahan, David, ed. From Natural Philosophy to the Sciences: Writing the History of Nineteenth-Century Science. Chicago: University of Chicago Press; 2003.

4. Numbers, Ronald; Lindberg, David, eds. When Science and Christianity Meet. Chicago: University of Chicago Press; 2003.

5. De Cruz, Helen, "Religion and Science", The Stanford Encyclopedia of Philosophy (Fall 2018 Edition), Edward N. Zalta (ed.).

6. Kurjak A, Barišić LS, Ahmed B, Porović S, Hasanović A. Beginning of human life: Science and Religion closer and closer. In: Science and Religion: Synergy not Skepticism; Asim Kurjak, Frank A Chervenak, Laurence B McCullough, Aziz Hasanović, eds. Jaypee Brothers Health Science Publishers (P) Ltd (New Delhi, London, Philadelphia, Panama), 2018; p. 21-52.

7. Evolution Resources: Compatibility of Science and Religion. Science, Evolution, and Creationism. National Academies of the United States; 2008.

8. Kurjak A, Carrera JM. The Beginning of Human LifeScientific and Religious Controversies. In: Textbook of Perinatal Medicine (Volume 1); editors: Kurjak A, Chervenak FA. Jaypee Brothers Health Science Publishers (P) Ltd (New Delhi, London, Philadelphia, Panama), 2015; p. 163-176.

9. Kurjak A, Spalldi Barišić L, Delic T, Porović S. Facts and Doubts about the Beginning of the Human Life and Personality. Donald School Journal of Ultrasound in Obstetrics and Gynecology 2016;10(3): 205-213.

10. Einstein A. Personal God Concept Causes Science-Religion Conflict. The Science News-Letter. 21 Sept. 1940;38(12): 181-182.

11. In "Science, Philosophy and Religion, A Symposium" published by the Conference on Science, Philosophy and Religion in Their Relation to the Democratic Way of Life, Inc., New York in 1941. "Albert Einstein Religion and Science". Sacredtexts.com

12. Barbour I. Issues in Science and Religion, New York: Vantage; 1966.

13. Torrance T.F. Theological Science. London: Oxford University Press. 1969.

14. Barbour I. When Science Meets Religion: Enemies, Strangers, or Partners? New York: Harpers Collins; 2000.

15. Clark Kelly J. Religion and the Science Origins. Historical and contemporary perspectives. New York: Palgrave Mac Millan; 2014.

16. Clark Kelly J, Barett J.L. " Reidian Religious Epistemology and the Cognitive Science of Religion", Journal of the American Academy of Religion. 2011;79:639-675.

17. Gould SJ. Non overlapping Magisteria. In Intelligent Design Creationism and Its Critics. Pennock (ed). Cambridge, Ma. MIT Press. 2001;739:737-749.

18. Dawes G. Galileo and the Conflict between Religion and Science. London and New York: Routledge; 2016.

19. Bowler P. Reconciling Science and Religion: The Debate in Early- Twentieth-Century Britain, Chicago: University of Chicago Press; 2001.

20. Van Huyssteen, Wentzel J. Duet or Duel? Theology and Science in a Postmodern World. London: SCM Press. 1998.

21. Durkheim E. The Elementary Forms of the Religious Life: A Study in Religious Sociology (translated by J.W.Swain). London: Allen and Unwin; 1915.

22. Freud S. Die Zukunft einer Illusion. Leipzig. Wien \& Zurich: Internationaler Psychoanalytischer Verlag; 1927.

23. Collons F. The language of God: A scientists presents evidence for belief. New York: Free Press; 2006.

24. Gervais W.M, Norenzayan A. Analytic Thinking Promotes Religious Disbelief. Science. 2012;336:493-496. 
25. Kurjak A. The beginning of human life and its modern scientific assessment. Clin Perinatol 2003;30:27-44.

26. Origins of the Universe. National Geographic. www.nationalgeographic.com/science/space/universe/origins-of-the-universe/

27. Pitts J.B. Why the Big Bang Singularity Does not Help the Kalam Cosmological Argument for Theism. British Journal for the Philosophy of Science. 2008;59:675-708.

28. Godfrey J.The Pope and the Ontogeny of Person (commentary). Nature. 1995;273:100.

29. Ventura-Junca P, Santos M.J. The beginning of life of a new human being from the scientific biological perspective and its bioethical implications. Biol Res 2011;44: 201-2017.

30. Rolston H. Science, religion, and the future. In: Religion and Science History, Method, Dialogue, W. Mark Richardson and Wesley J. Wildman, eds. Routledge: New York, 1996, pages 21-82.

31. Mayr E. The growth of biological thought. Harvard University Press, Belnap Press: Cambridge, 1982, page 81.

32. Serra A, Colombo R. Identity and status of the human embryo: The contribution of biology. In: de Dios Vial Correa, Sgreccia E (eds). Identity and statute of human embryo. 1998;128.

33. Beller FK, Zlatnik GP. The beginning of human life. Journal of Assisted Reproduction and Genetics. 1995;12(8):477-83.

34. Kurjak A. When does human life begin? Encyclopedia Moderna. 1992;383-390.

35. Liggins Graham (Mont). Foreword. In Nathanielsz P.W. "Life before birth and the time to be born." Promethean Press Ithaca, New York. 1992.

36. Gilbert SF. Developmental biology. Sunderland, Mass. Sinauer Associates. 1991;3.

37. Scarpelli EM. Postnatal through adult human life and the scientific deception. In: Atti del I Congresso Nazionale della Societa Italiana di Medicina Materno Fetale, Rome, March 17-21, 2003. Medimond (International Proceedings): Bologna, Italy. 2003;29-36.

38. Moore KL, Persaud TVN. The developing human: Clinically oriented embryology. 7th ed. Philadelphia: WB Saunders. 2003.

39. Carlson BM; Human Embryology and develop. Biology 2004.

40. Moore KL. The Developing Human: Clinically Oriented Embryology, 10th edition. Philadelphia, PA: Saunders, 2016; (p. 11).

41. Schoenwolf, G. C. Larsen's Human Embryology, 5th edition. Philadelphia, PA: Elsevier, Saunders, 2015; (p. 2, 14).

42. Scarpelli EM. Personhood: A biological phenomenon. J Perinat Med. 2001;29:417-426.

43. Moore KL. The Developing Human: Clinically Oriented Embryology, WB Saunders Co, Philadelphia, 1974; (p.1).

44. Lee June P, de Miranda F. When Human Life Begins. American College of Pediatrcians, March 2017.

45. Vjugina U, Evans J.P. New insights into the molecular basis of mammakian sperm-egg membrane interactions. Frontiers in Bioscience. 2008;13:2:462-76.

46. Oren-Suissa $\Omega$, Podbilewicz B. Cell fusion during development. Trends in Cečč Biology. 2007;17:11: 537-46 cited in, Condic ML. When does human life begins? A scientific perspective. Westchester Institute White Paper 2008; 1(1). The Westchester Institute for Ethics and the Human Person. Thornwood, NY; (p.3).

47. Condic ML. When does human life begin? A scientific perspective. Westchester Institute White Paper 2008; 1(1). The Westchester Institute for Ethics \& the Human Person. Thornwood, NY; (p.5).
48. ACOG Committee Opinion: Committee on Ethics: Preembryo research: History scientific background, and ethical considerations. Int J Gynecol Obstet. 1994;45:291-301.

49. Jirasek JE. An Atlas of the human embryo and fetus. NewYorkLondon: Parthenon Publishing 2001.

50. Declaration of Professors from Five Faculties of Medicine and Surgery of the universities of Rome, organizers of the Conference: The Embryo as a Patient.

51. Kurjak A, Stanojevic M, Azumendi G, Carrera JM. The potential of four-dimensional ultrasonography in the assessment of fetal awareness. J Perinat Med 2005;33:46-53.

52. Watson J.D. Crick F. Genetic implications of the structure of DNA. Nature. 1953;171: 964-967.

53. Badregal P, Shand B, Santos MJ, Ventura-Junca P. Contribution of epigenetics to understand human development. Rev Med Chile 2010;138:366-372.

54. Santos MJ. Manipulacion genetica de seres humanos. Ars Medica 1006;13:91-102.

55. Sass HM. Brain life and brain death: A proposal for normative agreement. J Med Philos 1989;14:45-59.

56. Veatch RM. The beginning of full moral standing. In: The beginning of human life, FK Beller, RF Weir (eds). Dordrecht, Kluwer. 1994, pp. 19.

57. Knutson AL. When does human life begin? Viewpoints of public health professionals. Am J Publ Health. 1967;57: 2167.

58. Inoue N, Okabe M. Sperm-egg fusion assay in mammals. Methods Mol Biol. 2008; 475:335-345.

59. Spalldi Barišić L, Kurjak A, Pooh K. R et al. Antenatal detection of fetal syndromes by ultrasound: From a single piece to a complete puzzle. Donald School J Ultrasound Obstet Gynaecol 2016;10(1):63-77.

60. Spalldi Barišić L, Stanojević M, Kurjak A, et al. Diagnosis of fetal syndromes by three- and four- dimensional ultrasound: is there any improvement? J. Perinat. Med. 2017;45(6):651-665.

61. Engelhardt HT. Jr. The foundation of bioethics. New York Oxford University Press. 1986.

62. Dunstan GR. The moral status of the human embryo. A tradition recalled. J Med Ethics. 1984;10:38-44.

63. Chervenak FA, McCullough LB, Kurjak A. Ethical implications of the embryo as a patient. In: Kurjak A, Chervenak FA, Carrera JM. The embryo as a patient. Parthenon Publishing Group New York London. 2001;226-30.

64. Curran CE. Abortion: Contemporary debate in philosophical and religious ethics. In Reich WT (ed). Encyclopedia of Bioethics. New York Macmillan. 1978;17-26.

65. Ruddick W, Wilcox W. Operating on the fetus. Hastings Cen Report. 1982;12:10-4.

66. McCullogh LB, Chervenak FA. Ethics in Obstetrics and Gynecology. New York. Oxford University Press. 1994.

67. Connery JR Jr. The ancients and medievals on abortion. In: Abortion and Constitution, Horan DJ, Grant ER, Cunningham PC (eds). Washington DC, Georgetown University Press. 1987:124.

68. Pierre F, Soutoul JH. "Medical and legal complications." J Gynecol Obstet Biol Reprod (Paris). 1994;23(5):516-519.

69. Ford NM. When did I begin? Conception of the human individual in history, philosophy and science, Cambridge: Cambridge University Press. 1991;137-46.

70. McLaren A. Prelude to embryogenesis, in the Ciba Foundation, Human Embryo Research, Yes or No? London, New York: Tavistock. 1986;12:5-23. 
71. Abel F. Nascita e morte dell'uomo: Prospective della biologia e della medicina, in S. Biolo, ed. Nascita e morte dell'uomo. Problemi filosofici e scientifici della bioetica, Genova: Marieti 1993:37-53.

72. McCormick KA. Who or what is the preembryo? Kennedy Instit Ethics J. 1991;1:24.

73. Mahoney SJ. Bioethics and belief. London, Sheed and Ward. 1984;80.

74. Johnson M. Delayed hominization. Reflections on some recent Catholic claims for delayed hominization. Theological Studies. 1995;56:743-63.

75. Congregation for the Doctrine of the Faith, Instruction on respect for human life in its origin and on the dignity of procreation "Donum Vitae" (February 12, 1987), Acta Apostolicae Sedis. 1988;80:70-102.

76. Ford NM. When did I begin? Cambridge University Press. 1991.

77. Beazley JM. Fetal assessment from conception to birth. In: Kurjak A (ed). Recent advances in ultrasound diagnosis. Amsterdam: Excerpta medica. 1980;128.

78. Kurjak A. Kada pocinje zivot. In: Kurjak A, ed. Očekujuci novorođenče, Zagreb: Naprijed. 1987;18-28.

79. Mastroianni Jr L. Ethical aspects of fetal therapy and experimentation. In: Schenker JG, Weinstein D, editors. The intrauterine life: Management and therapy. Amsterdam: Excerpta Medica. 1986;3-10.

80. Beller FK, Reeve J. Brain life and brain death: The anencephalic as an explanatory example. J Med Philos. 1989;14:5-20.

81. Brody B. Abortion and the sanctity of human life: A philosophical view. Cambridge, MIT Press. 1975, pp. 109.

82. Sass HM. The moral significance of brain-life-criteria. In: The beginning of human life, FK Beller, RF Weir RF (eds). Dordrecht, Kluwer; 1994. pp. 57-70.

83. Kupesic $S$. The first three weeks assessed by transvaginal color Doppler. J Perinat Med. 1996;24:310-317.

84. Kupesic S, Kurjak A, Ivancic-Kosuta M. Volume and vascularity of the yolk sac. J Perinat Med. 1999;27:91-96.

85. Kurjak A, Predanic M, Kupesic S. Transvaginal color Doppler study of middle cerebral artery blood flow in early normal and abnormal pregnancy. Ultrasound Obstet Gynecol. 1992;2:424-428.

86. Kurjak A, Kupesic S. Doppler assessment of the intervillous blood flow in normal and abnormal early pregnancy. Obstet Gynecol. 1997;89:252-256.

87. Kurjak A, Kupesic S, Hafner T. Intervillous blood flow in normal and abnormal early pregnancy. Croatian Med J. 1998;39(1):10.

88. Kurjak A, Kupesic S. Three-dimensional transvaginal ultrasound improves measurement of nuchal translucency. J Perinat Med. 1999;27:97-102.

89. Kurjak A, Kupesic S, Banovic I, Hafner T, Kos M. The study of morphology and circulation of early embryo by three-dimensional ultrasound and power Doppler. J Perinat Med. 1999;27:145-57.

90. Lee A. Four-dimensional ultrasound in prenatal diagnosis: Leading edge in imaging technology. Ultrasound Rev Obstet Gynecol. 2001;1:144-148.

91. Campbell S. 4D, or not 4D: That is the question. Ultrasound Obstet Gynecol. 2002;19:1-4.

92. de Vries JI, Visser GH, Prechtl HF. The emergence of fetal behaviour. I. Qualitative aspects. Early Hum Dev. 1982;7: 301-22.
93. de Vries JI, Visser GH, Prechtl HF. The emergence of fetal behaviour. I. Qualitative aspects. Early Hum Dev. 1985;12:99-120.

94. Kurjak A, Vecek N, Hafner T, Bozek T, Funduk-Kurjak B, Ujevic B. Prenatal diagnosis: what does four-dimensional ultrasound add? J Perinat Med. 2002;30:5762.

95. Kurjak A, Azumendi G, Vecek N, Kupesic S, Solak M, Varga $\mathrm{D}$, et al. Fetal hand movements and facial expression in normal pregnancy studied by four-dimensional sonography. J Perinat Med. 2003;31:496-508.

96. Okado N, Kojima T. Ontogenity of the central nervous system: Neurogenesis, fibre connection, synaptogenesis and myelinization in the spinal cord. In Prechtl HFR, ed. Continuity of neural functions from prenatal to postnatal life. Oxford: Blackwell Scientific. 1984;46-64.

97. Kurjak A, Azumendi G, Andonotopo W, Salihagic-Kadic A. Three- and four-dimensional ultrasonography for the structural and functional evaluation of the fetal face. Am J Obstet Gynecol 2007;196:16-28.

98. Kurjak A, Miskovic B, Andonotopo W, Stanojevic M, Azumendi G, Vrcic H. How useful is 3D and 4D ultrasound in perinatal medicine? J Perinat Med 2007;35:10-27.

99. Kurjak A, Miskovic B, Stanojevic M, Amiel Tison C, Ahmed B, Azumendi G, Vasilj O, Andonotopo W, Turudic T, Salihagic-Kadic A. New scoring system for fetal neurobehavior assessed by three- and four-dimensional sonography. J Perinat Med 2008;36(1):73-81.

100. Pooh RK, Kurjak A. Recent advances in 3D assessment of various fetal anomalies. Donald School Journal of Ultrasound in Obstetrics and Gynecology 2009;3(3):1-25.

101. Pooh RK, Shiota K, Kurjak A. Imaging of the human embryo with magnetic resonance imaging microscopy and highresolution transvaginal 3-dimensional sonography: human embryology in the 21st century. Am J Obstet Gynecol 2011;204:77.e1-16.

102. Pooh RK, Kurjak A. Three-dimensional/Four-dimensional Sonography moved Prenatal Diagnosis of Fetal Anomalies from the Second to the First Trimester of Pregnancy. Donald School Journal of Ultrasound in Obstetrics and Gynecology 2012;6(4):376-390.

103. Pooh RK, Kurjak A. Novel application of three-dimensional HDlive imaging in prenatal diagnosis from the first trimester. J Perinat Med 2014;43(2):147-58

104. Kurjak A, Spalldi Barisic L, Stanojevic M, Salihagic Kadic A, Porovic S. Are We Ready to investigate Cognitive Function of Fetal Brain? The Role of Advanced Four-dimensional Sonography. Donald School Journal of Ultrasound in Obstetrics and Gynecology 2016;10(2):116-124.

105. Kurjak A, Spalldi Barisic L, Delic T, Porovic S, Stanojevic M. Facts and Doubts about the Beginning of Human Life and Personality. Donald School Journal of Ultrasound in Obstetrics and Gynecology 2016;10(3):205-213.

106. Kurjak A. Editorial. 3D/4D Sonography. J. Perinat. Med. 2017.

107. Pooh RK, Kurjak A. Donald School Atlas of Advanced Ultrasound in Obstetrics and Gynecology. Jaypee Brothers, New Delhi, 2015.

108. Salihagic-Kadic A, Kurjak A, Medić M, Andonotopo W, Azumendi G. New data about embryonic and fetal neurodevelopment and behavior obtained by 3D and 4D sonography. J Perinat Med 2005; 33: 478-490.

109. Kurjak A, Antsaklis P, Stanojević M, Vladareanu R, Vladareanu S, Moreira Neto R, Spalldi Barišić L, Porović S, Delić T. 
Multicentric studies of the fetal neurobehavior by KANET test. J. Perinat. Med. 2017;45(6):717-727.

110. Kurjak A, Spalldi Barišić L, Stanojević M, et al. Are We Ready to investigate Cognitive Function of Fetal Brain? The Role of Advanced Four-dimensional Sonography. Donald School Journal of Ultrasound in Obstetrics and Gynecology. 2016;10(2):116-124.

111. Salihagić Kadić A, Kurjak A. Cognitive functions of the fetus. Ultraschall in der Medizin. 2018;39(2):181-189.

112. Pooh RK. A New Field of 'Fetal Sono-ophthalmology' by 3D HDlive Silhouette and Flow. Donald School J Ultrasound Obstet Gynecol. 2015;9(3):221-222.
113. Pooh RK, Kurjak A. Novel application of three-dimensional HDlive imaging in prenatal diagnosis from the first trimester. J Perinat Med. 2015;43:147-158.

114. Pooh, RK. Neuroanatomy visualisation by 2D and 3D. In: Pooh RK, Kurjak A, editors. Fetal neurology. New Delhi: Jaypee Brothers Medical Publisers (P) Ltd; 2009. p. 15-38.

115. Kurjak A, Barišić LS, Ahmed B, Porović S, Hasanović A. Beginning of human life: science and religion closer and closer. In: Science and Religion: Synergy not Skepticism; Asim Kurjak, Frank A Chervenak, Laurence B McCullough, Aziz Hasanović, eds. Jaypee Brothers Medical Publishers (P) Ltd (New Delhi, London, Panama), 2018, p. 21-52. 